\title{
Effects of ocean acidification on toxicity of two trace metals in two marine molluscs in their early life stages
}

\author{
Xiaoyu Guo ${ }^{1,2,4}$, Miaoqin Huang ${ }^{3,4}$, Bo Shi ${ }^{3,4}$, Weiwei You ${ }^{3,4,5}$, Caihuan $\mathrm{Ke}^{3,4,5, *}$ \\ ${ }^{1}$ College of Oceanology and Food Science, Quanzhou Normal University, Quanzhou 362000, PR China \\ ${ }^{2}$ Fujian Province Key Laboratory for the Development of Bioactive Material from Marine Algae, \\ Quanzhou Normal University, Quanzhou 362000, PR China \\ ${ }^{3}$ State Key Laboratory of Marine Environmental Sciences, Xiamen University, Xiamen 361102, PR China \\ ${ }^{4}$ College of Ocean and Earth Sciences, Xiamen University, Xiamen 361102, PR China \\ ${ }^{5}$ State-Province Joint Engineering Laboratory of Marine Bioproducts and Technology, Xiamen University, Xiamen 361102, \\ PR China
}

\begin{abstract}
Ocean acidification (OA) is usually thought to change the speciation of trace metals and increase the concentration of free metal ions, hence elevating metal bioavailability. In this study, embryos of the oyster Crassostrea angulata and abalone Haliotis discus hannai were cultured under $4 \mathrm{pCO}_{2}$ conditions $(400,800,1500$ and $2000 \mu \mathrm{atm})$ with $\mathrm{Cu}$ and $\mathrm{Zn}$ added. Fertilization rate was measured $2 \mathrm{~h}$ post-fertilization (hpf), while larval deformation and larval shell length were measured $24 \mathrm{hpf}$. Our results show that OA can alleviate $\mathrm{Cu}$ and $\mathrm{Zn}$ inhibition of $\mathrm{C}$. angulata fertilization by 86.1 and $26.4 \%$ respectively, and $\mathrm{Zn}$ inhibition of $H$. discus hannai fertilization by $43.7 \%$. However, OA enhanced the inhibitory effect of $\mathrm{Cu}$ on fertilization of $H$. discus hannai by $34.7 \%$. OA enhanced the toxic effect of $\mathrm{Cu}$ on larval normality of $C$. angulata by $22.0 \%$ and the effect of $\mathrm{Cu}$ and $\mathrm{Zn}$ on larval normality of $H$. discus hannai by 71.4 and $37.2 \%$, respectively. OA also enhanced the inhibitory effects of $\mathrm{Cu}$ and $\mathrm{Zn}$ on larval calcification in $H$. discus hannai by 8.8 and $8.6 \%$, respectively. However, OA did not change the effect of $\mathrm{Cu}$ on the calcification of $C$. angulata larvae. OA decreased Zn inhibition of oyster larval calcification from 3.1 to $1.5 \%$. Based on our results, the toxic effects of metal on early development of molluscs are not always increased by rising $\mathrm{pCO}_{2}$ and differ across developmental stages, egg structure and species. This complexity suggests that caution should be taken when carrying out multiple environmental stressor tests on molluscan embryos.
\end{abstract}

KEY WORDS: Oyster · Abalone $\cdot$ Ocean acidification $\cdot$ Trace metal $\cdot$ Fertilization $\cdot$ Larvae

\section{INTRODUCTION}

Carbon dioxide $\left(\mathrm{CO}_{2}\right)$ discharged by anthropogenic activities has caused a sharp increase in atmospheric $\mathrm{CO}_{2}$. In 2004, atmospheric $\mathrm{pCO}_{2}$ had risen from the preindustrial concentration of $280 \mu \mathrm{atm}$ to 380 patm (Sabine et al. 2004); by 2017 it had risen to 405.0 uatm (Lindsey 2020). Approximately one third of anthropogenic $\mathrm{CO}_{2}$ is absorbed by the ocean,

${ }^{*}$ Corresponding author: chke@xmu.edu.cn thereby causing reduced $\mathrm{pH}$ and calcium carbonate saturation, and it is predicted that $69 \%$ of the surface ocean will acidify by more than $0.2 \mathrm{pH}$ units relative to preindustrial levels by the end of the $21^{\text {st }}$ century (Gattuso et al. 2015). In addition, in coastal seawater, eutrophication due to anthropogenic activities could promote the production of algae, whose decomposition and remineralization would release large amounts of $\mathrm{CO}_{2}$, leading to the acidification of subsurface sea-

(C) The authors 2020. Open Access under Creative Commons by Attribution Licence. Use, distribution and reproduction are unrestricted. Authors and original publication must be credited. 
water. Therefore, coastal water which receives massive terrestrial input may be affected by both ocean acidification (OA) and local acidification, and is predicted to suffer further $\mathrm{pH}$ reduction compared with offshore seawater in the future (Cai et al. 2011). In a marginal sea of China (Yellow Sea), seasonal acidification has been observed in bottom seawater with a $\mathrm{pH}$ value of 7.90 ( $\mathrm{pH}$ is expressed in total scale) and is predicted to further reduce to a $\mathrm{pH}$ of $7.80-7.85$ by 2050 (Zhai 2018).

Increased $\mathrm{pCO}_{2}$ can directly affect physiological functions controlling gas exchange in marine organisms. Elevated ambient $\mathrm{CO}_{2}$ could reduce the $\mathrm{pCO}_{2}$ gradient from aquatic animals to their environment, hence inhibiting $\mathrm{CO}_{2}$ excretion and causing hypercapnia which leads to acidosis (Heuer \& Grosell 2014). In addition, decreased calcium carbonate saturation may hinder calcification of marine organisms, resulting in thinner and smaller shells, making them more vulnerable to predators (Gazeau et al. 2013). The effects of OA on embryos and larvae of calcareous marine organisms have been extensively reviewed (Byrne 2010, 2011, 2012, Dupont et al. 2010, Kroeker et al. 2013). There is compelling evidence that OA can adversely affect early life stages of these organisms, with biological effects including reduced fertilization, hatching, growth and calcification, and increased larval deformation.

In addition to $\mathrm{OA}$, trace metals are another environmental threat, and toxicity of trace metals to marine molluscan embryos and larvae has been studied in oysters Crassostrea virginica (Calabrese et al. 1977), mussels Mytilus edulis (Johnson 1988) and abalone Haliotis rubra (Gorski \& Nugegoda 2006). Toxicity of trace metals occurs through non-specific binding with enzymes and transcription factors or through metal-induced oxidative damage to proteins and critical cellular components (Stohs \& Bagchi 1995, Ringwood et al. 1998, Geret et al. 2002, Dailianis et al. 2005, Valko et al. 2005, Martelli et al. 2006). Coastal regions may be affected by both OA and trace metal pollution from various sources, including wastewater discharge, antifouling paints and coastal engineering. After decades of rapid industrial expansion and ineffective pollution management, trace metal contamination has frequently been observed in coastal environments in China (Pan \& Wang 2012).

OA likely changes the speciation of metals by increasing concentrations of free ions such as $\mathrm{Cu}$ and $\mathrm{Zn}$ (Millero et al. 2009), thereby increasing bioavailability of trace metals and aggravating their toxicity in estuaries. The combined effects of OA and trace metals have been studied in polychaetes (Lewis et al.
2013), molluscs (Lacoue-Labarthe et al. 2009, Ivanina et al. 2013, Götze et al. 2014, Belivermiş et al. 2016, Shi et al. 2016) and copepods (Pascal et al. 2010, Fitzer et al. 2013, Li et al. 2017). In contrast to predictions that OA would increase the toxicity of some trace metals (Millero et al. 2009), the results of these studies showed complex responses of marine organisms to the combined influence of OA and trace metals. For example, fertilization of the polychaete Pomatoceros lamarckii was unaffected by adding $\mathrm{Cu}$ to ambient or acidified seawater, while larval survival significantly decreased when $\mathrm{Cu}$ and OA co-occurred relative to OA only (Lewis et al. 2013). OA enhanced $\mathrm{Cu}$ and $\mathrm{Cd}$ accumulation in mantle tissue of oysters C. virginica and hard clams Mercenaria mercenaria, and proteasome responses to metals in those species were also modulated by OA (Götze et al. 2014). Cd accumulation in 3 bivalve species (Mytilus edulis, Tegillarca granosa and Meretrix meretrix) was significantly higher in $\mathrm{CO}_{2}$-acidified seawater (Shi et al. 2016). Greater decline in copepod naupliar production was observed in seawater with decreasing $\mathrm{pH}$ when $\mathrm{Cu}$ was added than in seawater with decreasing $\mathrm{pH}$ alone; however, $\mathrm{Cu}$ addition enhanced copepod growth regardless of $\mathrm{pH}$ level (Fitzer et al. 2013). OA could even alleviate the toxic effects of $\mathrm{Hg}$ on copepod reproduction by reducing its accumulation (Li et al. 2017). To date, however, research concerning the combined effects of OA and trace metals on molluscan embryos and larvae remains scarce.

Oysters are an important ecosystem component in controlling primary production, maintaining water clarity, providing habitats for benthic organisms and transferring particles from water to sediment (Dame et al. 1989, Ulanowicz \& Tuttle 1992, Dame \& Libes 1993, Dame 1996). In addition, oysters are an economically important aquaculture species and as such are extensively cultured in China. In 2017, $4879422 \mathrm{t}$, with a value of 5.26 billion USD were harvested in China (www.fao.org). Abalone is also an important aquaculture species, and China accounted for $88.2 \%$ of global output in 2017 (www.fao.org).

In the present study, the combined effects of OA and trace metals ( $\mathrm{Cu}$ and $\mathrm{Zn}$ ) on embryos and larvae of oysters $C$. angulata and abalone $H$. discus hannai were studied to test whether OA could aggravate trace metal toxicity in molluscs. Oysters and the abalone were selected as study organisms because they are the most widely cultured species along the southern coast of Fujian Province, China. $\mathrm{Cu}$ and $\mathrm{Zn}$ were used as test trace elements because the 2 metals are the main pollutants in the Jiulong River estu- 
ary on the southern coast of Fujian Province (Wang et al. 2011).

\section{MATERIALS AND METHODS}

\subsection{Construction of high-pCO $\mathrm{CO}_{2}$ seawater system}

The design of the experimental system followed that of a previous study (Guo et al. 2015), with several improvements. The principle of this system is mixing $\mathrm{CO}_{2}$-enriched air with seawater to produce acidified seawater. Air was supplied from an air compressor (AT3000-120L FINETM) and passed through a freeze dryer (YD-3 YIYANGTM), a pressure swing adsorption dryer (YS-3 YIYANG ${ }^{\mathrm{TM}}$ ) and an allochroic silica gel column. To avoid the disturbance of $\mathrm{CO}_{2}$ produced by human activities in the laboratory air, a pipe was connected with the gas inlet of the air compressor on one end, and the other end was placed in the open air outside the lab. The 2 dryers were used to remove excess water vapor so that valves in the system could not be affected by moisture. The silica gel served as an indicator to ensure that all water vapor was removed. The dried air was conducted through a gas pressure regulator (GR300-08 AIRTAC ${ }^{\text {TM})}$ and a filter (GF300-08 AIRTAC ${ }^{\mathrm{TM}}$ ) to stabilize its pressure and remove particles. After that, the air passed through another gas pressure regulator (GPR300-08 AIRTACTM) and a needle valve (LZB$6 \mathrm{WB}(\mathrm{F})$ SHUANGHUAN ${ }^{\mathrm{TM}}$ ) to obtain a fixed pressure and flow rate. $\mathrm{CO}_{2}$ was supplied from a cylinder with a purity of $99.99 \%$ and manipulated similarly to air, so $\mathrm{CO}_{2}$ with a fixed pressure and flow rate was obtained.

Both the air and the $\mathrm{CO}_{2}$ were conducted into buffering bottles with a Venturi pipe and were well mixed. The mixture of air and $\mathrm{CO}_{2}$ was divided into 2 parts, one for the experiment and the rest conducted through a bypass where a $\mathrm{CO}_{2}$ sensor (K30FR SENSEAIR ${ }^{\mathrm{TM}}$ ) and a paperless recorder (NHR7100 $\mathrm{HR}^{\mathrm{TM}}$ ) were installed to detect the $\mathrm{CO}_{2}$ concentration in the system. The paperless recorder received the analog signal from the $\mathrm{CO}_{2}$ sensor, and the $\mathrm{CO}_{2}$ concentration was displayed on its panel. When setting the $\mathrm{pCO}_{2}$ level, a needle valve (TZF-1, Trieder) in the $\mathrm{CO}_{2}$ line was adjusted to change the $\mathrm{CO}_{2}$ flow rate, while that in the air line remained unchanged, until the $\mathrm{CO}_{2}$ concentration in the recorder reached the target value. Finally, $\mathrm{CO}_{2}$-enriched air was bubbled into $0.22 \mu \mathrm{m}$ filtered seawater (FSW) to achieve the required $\mathrm{pH}$ level when the gas-liquid equilibration was obtained (Fig. 1).

Four $\mathrm{pCO}_{2}$ conditions were established: $400 \mu \mathrm{atm}$, representing the current ambient atmospheric $\mathrm{CO}_{2}$ concentration; $800 \mu \mathrm{atm}$, representing an intermediate IPCC case scenario of $747 \mu \mathrm{atm}$ at the end of the $21^{\text {st }}$ century; $1500 \mu \mathrm{atm}$, corresponding to the upper limit of the $\mathrm{pCO}_{2}$ range observed in coastal regions affected by upwelling, including the Peruvian upwelling system (Friederich et al. 2008) and the California Current Ecosystem (Reum et al. 2016); and $2000 \mu \mathrm{atm}$, corresponding to the future $\mathrm{pCO}_{2}$ level of coastal seawater in which acidification is amplified by anthropogenic effects (Melzner et al. 2013) and which has already been used in several studies (e.g. Lopes et al. 2016, Wang et al. 2016). Temperature and $\mathrm{pH}$ were measured with a $\mathrm{pH}$ meter (Thermo Scientific Orion Star Series ${ }^{\mathrm{TM}}$ Benchtop) with a probe (8157BNUMD) calibrated with NBS buffer $(4.00,7.00$ and 10.00). A seawater sample $(500 \mathrm{ml})$ was taken from the tank and immediately fixed using $200 \mu \mathrm{l}$ of saturated mercuric chloride solution. Total alkalinity was determined by Gran acidimetric titration with an Apollo TA Analyzer (Cai \& Wang 1998). Salinity was measured with an optical

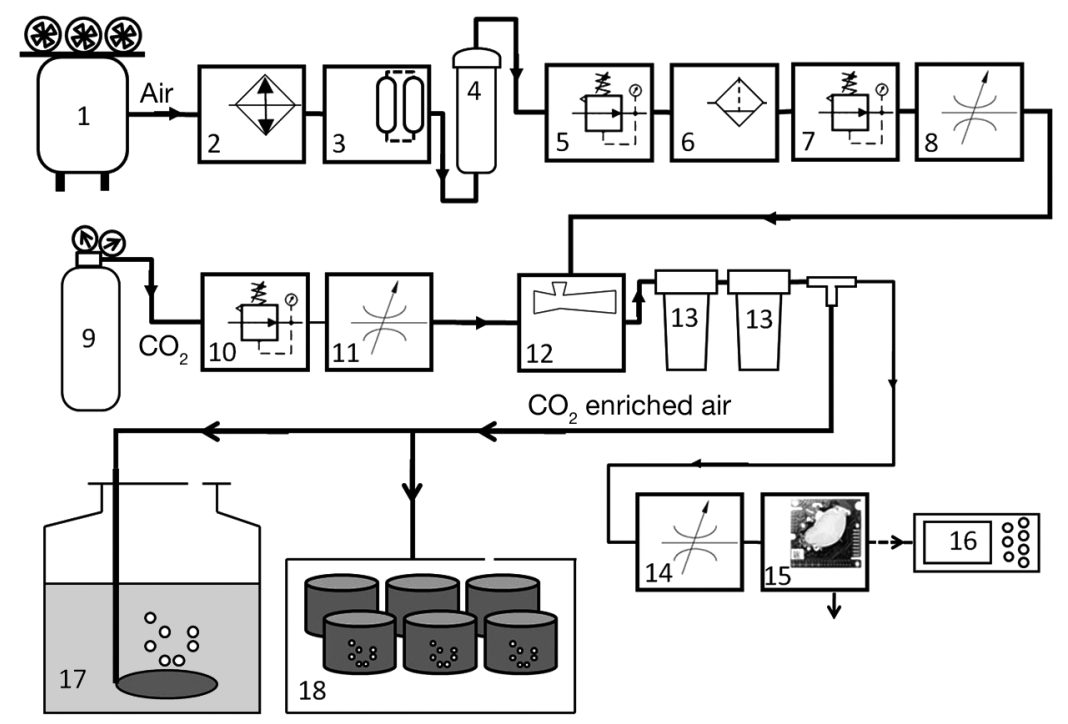

Fig. 1. Schematic of the instrument simulating ocean acidification (OA) for the molluscan larvae experiment. 1: air compressor, 2: freeze dryer, 3: pressure swing adsorption dryer, 4: allochroic silica gel column, 5: gas pressure regulator, 6: air filter, 7: gas pressure regulator, 8: needle valve, 9: $\mathrm{CO}_{2}$ cylinder, 10: gas pressure regulator, 11: needle valve, 12: venturi pipe, 13: buffering bottles, 14: needle valve, 15: $\mathrm{CO}_{2}$ sensor, 16: paperless recorder, 17: seawater tank, 18: chamber for larvae culture 
salinity meter gauge. Carbonate system parameters were calculated using CO2SYS software (version 2.1). The $\mathrm{pH}$, total alkalinity, temperature, salinity and other calculated data are listed in Table 1.

\subsection{Test solutions of metals under different $\mathrm{pCO}_{2}$ levels}

Metals used in tests were from inorganic salts $\left(\mathrm{CuSO}_{4} \cdot 5 \mathrm{H}_{2} \mathrm{O}\right.$ and $\left.\mathrm{ZnSO}_{4} \cdot 7 \mathrm{H}_{2} \mathrm{O}\right)$ and were all analytical grade. Stock solutions were made using deionized water and then diluted with filtered seawater of different $\mathrm{pCO}_{2}$ levels to obtain test solutions with different metal concentrations. Background metal concentrations of $\mathrm{Cu}$ and $\mathrm{Zn}$ in seawater were measured by the co-precipitation method of Sawatari et al. (1995) and were $0.91 \mu g \mathrm{l}^{-1}$ and $6.76 \mu \mathrm{g} \mathrm{l^{-1 }}$, respectively. Nominally, metal concentrations (above the seawater background levels) for the oyster fertilization tests were $0,10,20,50,80$ and $100 \mathrm{\mu g} \mathrm{l}^{-1}$ for $\mathrm{Cu}$ and $0,1,2,3$ and $4 \mu \mathrm{g} \mathrm{ml}^{-1}$ for $\mathrm{Zn}$. Metal concentrations for the oyster larvae tests were 0,5 and $10 \mu \mathrm{g} \mathrm{l}^{-1}$ for $\mathrm{Cu}$ and 0,25 and $50 \mu \mathrm{g} \mathrm{l} \mathrm{l}^{-1}$ for $\mathrm{Zn}$. Metal concentrations for the abalone fertilization tests were 0,30 , $60,150,240$ and $300 \mu \mathrm{g} \mathrm{l}^{-1}$ for $\mathrm{Cu}$ and $0,0.2,0.5,1,2$ and $4 \mu \mathrm{g} \mathrm{ml}^{-1}$ for $\mathrm{Zn}$. Metal concentrations for the abalone larvae tests were $0,2.5$ and $5 \mu \mathrm{g} \mathrm{l}^{-1}$ for $\mathrm{Cu}$ and $0,20,40$ and $60 \mathrm{\mu g} \mathrm{l}^{-1}$ for Zn. Metal concentrations used in larvae tests were approximately the same magnitude as those in the polluted sites in the Jiulong River estuary (Cu: 2.84-12.54 $\mu \mathrm{g} \mathrm{l}^{-1}$ and $\mathrm{Zn}$ : 4.81-19.92 $\mathrm{g} \mathrm{l} \mathrm{l}^{-1}$; Weng \& Wang 2014). The short duration $(\sim 2 \mathrm{~h})$ of fertilization tests allowed only transitory contact between gametes and metals, necessitating the use of higher metal concentrations than environmental levels to ensure an effect. Test solutions were prepared in $100 \mathrm{ml}$ volumetric flasks, transferred into $100 \mathrm{ml}$ polyethylene (PE) bottles with caps, sealed with parafilm, and stored for the biological tests. Metal concentrations in subsamples of test solutions were also measured, and the data are provided in Table A1 in the Appendix.

\subsection{Fertilization and larvae tests for oysters and abalone}

Adult oysters and abalone were obtained from FUDA aquaculture farm in Jinjiang, Fujian, China. The molluscs were transferred to the lab and acclimated for $7 \mathrm{~d}$ before the experiments, using the culturing method previously reported by Guo et al. (2015).

To obtain eggs and sperm from oysters, oyster shells were opened using an oyster shucker. Individuals with fully developed gonads were selected and put on an enamel tray. A 24-well plate with FSW in each well was used for gamete selection. The gonad was pierced with a $200 \mu$ pipette tip, and a $20 \mu l$ aliquot of gametes was removed and transferred into one well of the plate. A new pipette tip was used for each oyster and contact between tips was avoided to prevent undesired fertilization before the test. At $15 \mathrm{~min}$ post transfer, gametes in the wells were checked under an inverted microscope (DM IL LED Leica ${ }^{\mathrm{TM}}$ ). Eggs that were mature enough for fertilization were globular or pear-shaped, with a transparent nucleus in the center surrounded by densely packed granules. Suitable sperm were swimming rapidly. Eggs from 3 to 5 oysters were selected, pooled, and used to prepare a dense suspension in FSW. Eggs were then washed 2 to 3 times with FSW to remove undesired gonad debris. Sperm from 3 to 5 oysters were also selected, pooled, and made into a suspension with FSW. To obtain eggs and sperm from abalone, individuals with fully developed gonads were stimulated

Table 1. Mean \pm SD of water chemistry measurements and calcite and aragonite saturation state $(\Omega)$ of seawater in control and high-p $\mathrm{CO}_{2}$ groups. $\mathrm{n}=3$ for all treatments. Parameters such as $\mathrm{pCO}_{2}$, concentration of $\mathrm{CO}_{2}$, bicarbonate ions and carbonate ions and $\Omega$ were calculated by the CO2SYS software

\begin{tabular}{|lccrr|}
\hline Parameter & Control & $800 \mu \mathrm{atm}$ & $1500 \mu \mathrm{atm}$ & $2000 \mu \mathrm{atm}$ \\
\hline Temperature $\left({ }^{\circ} \mathrm{C}\right)$ & $24.7 \pm 0.1$ & $25.0 \pm 0.1$ & $24.4 \pm 0.2$ & $24.7 \pm 0.3$ \\
$\mathrm{pH}(\mathrm{NBS}$ scale) & $8.16 \pm 0.02$ & $7.93 \pm 0.01$ & $7.69 \pm 0.01$ & $7.60 \pm 0.02$ \\
Alkalinity $\left(\mu \mathrm{mol} \mathrm{kg}{ }^{-1}\right)$ & $2294.1 \pm 1.2$ & $2242.1 \pm 0.7$ & $2248.1 \pm 0.7$ & $2286.8 \pm 2.0$ \\
Salinity & $30.3 \pm 0.5$ & $30.3 \pm 0.5$ & $30.3 \pm 0.5$ & $30.3 \pm 0.5$ \\
$\mathrm{pCO}_{2}(\mu \mathrm{atm})$ & 423.3 & 808.3 & 1480.4 & 1884.4 \\
{$\left[\mathrm{CO}_{2}\right]\left(\mu \mathrm{mol} \mathrm{kg}{ }^{-1}\right)$} & 12.4 & 23.4 & 43.6 & 55.1 \\
{$\left[\mathrm{HCO}^{3-}\right]\left(\mu \mathrm{mol} \mathrm{kg}^{-1}\right)$} & 1831.4 & 1960.2 & 2079.3 & 2144.5 \\
$\left.\left[\mathrm{CO}_{3}{ }^{2-}\right](\mu \mathrm{mol} \mathrm{kg})^{-1}\right)$ & 191.6 & 116.4 & 1.74 & 59.0 \\
$\Omega \mathrm{cal}_{\Omega}$ & 4.78 & 1.91 & 1.13 & 1.47 \\
$\Omega$ ara & 3.12 & 1.90 & 0.96 \\
\hline
\end{tabular}


with UV-radiated seawater to produce gametes. Viable eggs and sperm were also selected, pooled and made into suspensions with FSW.

A complete 2 fixed factor factorial design was adopted in the biological tests: for example, there were 24 treatments $\left(4 \mathrm{pCO}_{2}\right.$ levels $\times 6 \mathrm{Cu}$ concentrations) in the oyster fertilization test. Each treatment was replicated 4 times, and embryos or larvae were cultured in $40 \mathrm{ml}$ polypropylene (PP) bottles. The bottles were placed in a chamber connected to a pipe that supplied $\mathrm{CO}_{2}$-enriched air from the system described in Section 2.1 so that a micro-environment with high $\mathrm{pCO}_{2}$ was maintained; this ensured that the water $\mathrm{pH}$ did not vary greatly during the experiment. Four chambers were used for each of the $4 \mathrm{pCO}_{2}$ levels, and each chamber contained a series of replicate bottles with different metal concentrations.

For both fertilization and larvae tests, a $20 \mu \mathrm{l}$ volume of egg suspension and $20 \mu \mathrm{l}$ of sperm suspension were added to each bottle to initiate fertilization. The volume of gamete suspension was small relative to the total volume of the test solution and had only a minor dilution effect on the metal concentration. Density of eggs in each was maintained at 10 eggs $\mathrm{ml}^{-1}$ for oysters and 2 eggs $\mathrm{ml}^{-1}$ for abalone to minimize the metabolic effects of embryos on the seawater $\mathrm{pH}$, while sperm amounts were adjusted to achieve a concentration of $10^{3} \mathrm{ml}^{-1}$ in the test solution. After adding the sperm suspension, the bottles were gently shaken for $10 \mathrm{~s}$ and then transferred into the chambers. The chambers were put in a thermo-static incubator with a set temperature of $25^{\circ} \mathrm{C}$ for oyster and $22^{\circ} \mathrm{C}$ for abalone. At $30 \mathrm{~min}$ after fertilization, the FSW was refreshed several times to remove excess sperm.

At $2 \mathrm{~h}$ post-fertilization (hpf), the fertilization test was terminated by adding $20 \mu \mathrm{l}$ buffered formalin to each bottle. Photos of the resulting embryos for fertilization rate and egg diameter measurements were taken using a CCD camera connected to a microscope (CX31 Olympus ${ }^{\mathrm{TM}}$ ). Fertilization rate (\%) was calculated by counting the number of cleaved embryos and the total number of eggs:

$$
\begin{aligned}
\text { Fertilization rate }= & (\text { no. cleaved embryos } / \\
& \text { no. total eggs }) \times 100
\end{aligned}
$$

Egg diameter was defined as the sum of the cytoplasm and vitelline layer according to Graham et al. (2006) and was measured with the software ImagePro Plus 6.0. Egg diameter was observed only for abalone.

At $24 \mathrm{hpf}$, the larvae test was terminated by adding $20 \mu \mathrm{l}$ buffered formalin to each bottle. Deformation and shell length were observed. Deformation rate (\%) was calculated following the methods of His et al. (1997) for oysters and Hunt \& Anderson (1990) for abalone.

$$
\begin{aligned}
\text { Deformation rate }= & (\text { no. deformed larvae } / \\
& \text { no. total larvae }) \times 100
\end{aligned}
$$

Approximately 50 embryos/larvae were randomly sampled from each bottle and observed under the microscope.

All the containers used for solution preparation and biological tests were soaked in 1:10 (v:v) nitric acid for at least $24 \mathrm{~h}$ and rinsed with deionized water 3 times before the experiment.

\subsection{Statistics}

Data on fertilization rate and larval deformation were arcsine and square root transformed to meet the assumption of homogeneity of variance for ANOVA. A 2-way ANOVA was performed with $\mathrm{pCO}_{2}$ and metal as fixed factors. Simple effects of $\mathrm{pCO}_{2}$ or metal were analyzed using a 1-way ANOVA with a Student-Newman-Keuls (SNK) post hoc test when interactions of the 2 factors were found. A KruskalWallis (KW) test was applied when data transformations failed to result in homogeneity of variance. Differences were considered significant if $p<0.05$. All statistical analyses were performed using SPSS v17.0.

\section{RESULTS}

\subsection{Combined effects of $\mathrm{OA}$ and trace metals on fertilization of Crassostrea angulata}

There was an interaction between $\mathrm{OA}$ and the effect of $\mathrm{Cu}$ on fertilization of $C$. angulata (2-way ANOVA, $F_{15,72}=95.5, \mathrm{p}<0.001$; Table 2). Fertilization was unaffected by rising $\mathrm{pCO}_{2}$ when no $\mathrm{Cu}$ was added (1-way ANOVA, $F_{3,15}=1.5, \mathrm{p}=0.27$ ); however, fertilization was significantly higher at high $\mathrm{pCO}_{2}$ than low $\mathrm{pCO}_{2}$ when $\mathrm{Cu}$ addition exceeded $10 \mathrm{\mu g} \mathrm{l}^{-1}$ (e.g. when $20 \mathrm{\mu g} \mathrm{l}^{-1}$ of $\mathrm{Cu}$ was added, fertilization rate increased $86.1 \%$ between 400 and $2000 \mu \mathrm{atm}$ $\mathrm{pCO}_{2}$ : SNK, $\mathrm{p}<0.001$; Fig. 2a). In other words, the toxicity of $\mathrm{Cu}$ to oyster fertilization was alleviated by increasing $\mathrm{pCO}_{2}$ in seawater.

An interaction also existed between $\mathrm{OA}$ and the effect of $\mathrm{Zn}$ on oyster fertilization (2-way ANOVA, $F_{12,60}=12.7, \mathrm{p}<0.001$; Table 2), with similar effects to those of the combined $\mathrm{OA}$ and 
Table 2. Results of 2-way ANOVA examining the combined effects of $\mathrm{pCO}_{2}$ and trace metals on embryonic and larval development of the oyster Crassostrea angulata and abalone Haliotis discus hannai. ${ }^{*} \mathrm{p}<0.05$

\begin{tabular}{|c|c|c|c|c|c|}
\hline Response variable & $\begin{array}{l}\text { Source of } \\
\text { variance }\end{array}$ & $\mathrm{df}$ & MS & $F$ & $\mathrm{p}$ \\
\hline $\begin{array}{l}\text { Fertilization of } \\
\text { C. angulata }\end{array}$ & $\begin{array}{l}\mathrm{CO}_{2} \\
\mathrm{Cu} \\
\mathrm{CO}_{2} \times \mathrm{Cu} \\
\text { Residual } \\
\mathrm{CO}_{2} \\
\mathrm{Zn} \\
\mathrm{CO}_{2} \times \mathrm{Zn} \\
\text { Residual }\end{array}$ & $\begin{array}{c}3 \\
5 \\
15 \\
72 \\
3 \\
4 \\
12 \\
60\end{array}$ & $\begin{array}{c}3088.5 \\
19046.8 \\
671.3 \\
7.0 \\
858.9 \\
7905.6 \\
90.9 \\
7.2\end{array}$ & $\begin{array}{c}439.4 \\
2710.0 \\
95.5\end{array}$ & $\begin{array}{l}<0.001^{*} \\
<0.001^{*} \\
<0.001^{*} \\
<0.001^{*} \\
<0.001^{*} \\
<0.001^{*}\end{array}$ \\
\hline $\begin{array}{l}\text { Fertilization of } \\
\text { H. discus hannai }\end{array}$ & $\begin{array}{l}\mathrm{CO}_{2} \\
\mathrm{Cu} \\
\mathrm{CO}_{2} \times \mathrm{Cu} \\
\text { Residual } \\
\mathrm{CO}_{2} \\
\mathrm{Zn} \\
\mathrm{CO}_{2} \times \mathrm{Zn} \\
\text { Residual }\end{array}$ & $\begin{array}{c}3 \\
5 \\
15 \\
72 \\
3 \\
5 \\
15 \\
72\end{array}$ & $\begin{array}{c}1144.1 \\
3980.1 \\
171.8 \\
27.2 \\
426.9 \\
21712.5 \\
168.8 \\
13.9\end{array}$ & $\begin{array}{c}42.1 \\
146.6 \\
6.3 \\
\\
30.6 \\
1556.9 \\
12.1\end{array}$ & $\begin{array}{l}<0.001^{*} \\
<0.001^{*} \\
<0.001^{*} \\
<0.001^{*} \\
<0.001^{*} \\
<0.001^{*}\end{array}$ \\
\hline $\begin{array}{l}\text { Egg diameter of } \\
\text { H. discus hannai }\end{array}$ & $\begin{array}{l}\mathrm{CO}_{2} \\
\mathrm{Cu} \\
\mathrm{CO}_{2} \times \mathrm{Cu} \\
\text { Residual } \\
\mathrm{CO}_{2} \\
\mathrm{Zn} \\
\mathrm{CO}_{2} \times \mathrm{Zn} \\
\text { Residual }\end{array}$ & $\begin{array}{c}1 \\
2 \\
2 \\
18 \\
1 \\
2 \\
2 \\
18\end{array}$ & $\begin{array}{c}2940.7 \\
5345.6 \\
1432.6 \\
33.8 \\
23.6 \\
22.9 \\
24.9 \\
1.8\end{array}$ & $\begin{array}{c}87.0 \\
158.2 \\
42.4 \\
\\
13.3 \\
12.9 \\
14.1\end{array}$ & $\begin{array}{l}<0.001^{*} \\
<0.001^{*} \\
<0.001^{*} \\
<0.001^{*} \\
<0.001^{*} \\
<0.001^{*}\end{array}$ \\
\hline $\begin{array}{l}\text { Deformation of } \\
\text { C. angulata larvae }\end{array}$ & $\begin{array}{l}\mathrm{CO}_{2} \\
\mathrm{Cu} \\
\mathrm{CO}_{2} \times \mathrm{Cu} \\
\text { Residual } \\
\mathrm{CO}_{2} \\
\mathrm{Zn} \\
\mathrm{CO}_{2} \times \mathrm{Zn} \\
\text { Residual }\end{array}$ & $\begin{array}{c}2 \\
2 \\
4 \\
27 \\
2 \\
2 \\
4 \\
27\end{array}$ & $\begin{array}{c}3719.3 \\
6723.6 \\
328.5 \\
2.9 \\
1853.3 \\
3619.1 \\
30.4 \\
11.2\end{array}$ & $\begin{array}{c}1261.3 \\
2280.1 \\
111.4 \\
\\
164.9 \\
322.0 \\
2.7\end{array}$ & $\begin{array}{r}<0.001^{*} \\
<0.001^{*} \\
<0.001^{*} \\
<0.001^{*} \\
<0.001^{*} \\
0.051\end{array}$ \\
\hline $\begin{array}{l}\text { Deformation of } \\
\text { H. discus hannai larvae }\end{array}$ & $\begin{array}{l}\mathrm{CO}_{2} \\
\mathrm{Cu} \\
\mathrm{CO}_{2} \times \mathrm{Cu} \\
\text { Residual } \\
\mathrm{CO}_{2} \\
\mathrm{Zn} \\
\mathrm{CO}_{2} \times \mathrm{Zn}\end{array}$ & $\begin{array}{c}2 \\
2 \\
4 \\
36 \\
2 \\
3 \\
6\end{array}$ & $\begin{array}{c}1468.7 \\
2442.9 \\
441.4 \\
9.0 \\
7860.4 \\
3617.9 \\
579.3\end{array}$ & $\begin{array}{c}162.6 \\
270.5 \\
48.9 \\
\\
543.2 \\
250.0 \\
40.0\end{array}$ & $\begin{array}{l}<0.001^{*} \\
<0.001^{*} \\
<0.001^{*} \\
<0.001^{*} \\
<0.001^{*} \\
<0.001^{*}\end{array}$ \\
\hline $\begin{array}{l}\text { Shell length of } \\
\text { C. angulata larvae }\end{array}$ & $\begin{array}{l}\mathrm{CO}_{2} \\
\mathrm{Cu} \\
\mathrm{CO}_{2} \times \mathrm{Cu} \\
\text { Residual } \\
\mathrm{CO}_{2} \\
\mathrm{Zn} \\
\mathrm{CO}_{2} \times \mathrm{Zn} \\
\text { Residual }\end{array}$ & $\begin{array}{c}2 \\
2 \\
4 \\
27 \\
2 \\
2 \\
4 \\
27\end{array}$ & $\begin{array}{c}184.5 \\
226.5 \\
3.8 \\
1.8 \\
255.3 \\
35.8 \\
1.7 \\
0.4\end{array}$ & $\begin{array}{c}104.0 \\
127.7 \\
2.1 \\
\\
574.5 \\
80.6 \\
3.7\end{array}$ & $\begin{array}{r}<0.001^{*} \\
<0.001^{*} \\
0.106 \\
<0.001^{*} \\
<0.001^{*} \\
0.015^{*}\end{array}$ \\
\hline $\begin{array}{l}\text { Shell length of } \\
\text { H. discus hannai larvae }\end{array}$ & $\begin{array}{l}\mathrm{CO}_{2} \\
\mathrm{Cu} \\
\mathrm{CO}_{2} \times \mathrm{Cu} \\
\text { Residual } \\
\mathrm{CO}_{2} \\
\mathrm{Zn} \\
\mathrm{CO}_{2} \times \mathrm{Zn} \\
\text { Residual }\end{array}$ & $\begin{array}{c}2 \\
2 \\
4 \\
27 \\
2 \\
3 \\
6 \\
36\end{array}$ & $\begin{array}{c}528.2 \\
301.1 \\
205.1 \\
17.6 \\
4183.5 \\
9920.3 \\
1098.9 \\
38.0\end{array}$ & $\begin{array}{c}30.1 \\
17.1 \\
11.7 \\
\\
110.2 \\
261.2 \\
28.9\end{array}$ & $\begin{array}{l}<0.001^{*} \\
<0.001^{*} \\
<0.001^{*} \\
<0.001^{*} \\
<0.001^{*} \\
<0.001^{*}\end{array}$ \\
\hline
\end{tabular}

$\mathrm{Cu}$ treatment. Fertilization was unaffected by $\mathrm{pCO}_{2}$ levels when no Zn was added, while fertilization was significantly higher at high $\mathrm{pCO}_{2}$ than at low $\mathrm{pCO}_{2}$ with increasing $\mathrm{Zn}$ addition (e.g. when $1 \mu \mathrm{gl}^{-1}$ of Zn was added, fertilization rate increased $26.4 \%$ between 400 and 2000 ratm $\mathrm{pCO}_{2}$ : SNK, p $<0.001$; Fig. 2b).

\subsection{Combined effects of $O A$ and trace metals on fertilization of Haliotis discus hannai}

There was an interaction between $\mathrm{OA}$ and the effect of $\mathrm{Cu}$ on fertilization of $H$. discus hannai (2-way ANOVA, $F_{15,72}=6.3, \mathrm{p}<0.001$; Table 2). For example, fertilization was not significantly different between $\mathrm{pCO}_{2} 400$ and 2000 patm when no $\mathrm{Cu}$ was added (1-way ANOVA, $F_{3,15}=0.49, \mathrm{p}=0.70$; Fig. 3a). However, fertilization was reduced by $34.7 \%$ at $2000 \mu$ atm when $150 \mu \mathrm{g} \mathrm{l}^{-1}$ of $\mathrm{Cu}$ was added (SNK, $\mathrm{p}<$ 0.001; Fig. 3a). Similarly, fertilization was reduced by $33.0 \%$ at 1500 uatm when $300 \mu \mathrm{g} \mathrm{l}^{-1}$ of $\mathrm{Cu}$ was added (SNK, p = 0.001; Fig. 3a). In other words, the toxicity of $\mathrm{Cu}$ to abalone fertilization was aggravated by increasing $\mathrm{pCO}_{2}$ in seawater.

In contrast, the toxicity of $\mathrm{Zn}$ to abalone fertilization was alleviated by increasing $\mathrm{pCO}_{2}$, and the interaction of these 2 factors was significant (2-way ANOVA, $F_{15,72}=12.1$, $\mathrm{p}<0.001$; Table 2). For example, fertilization was unaffected by $\mathrm{pCO}_{2}$ level when no (1-way ANOVA, $F_{3,15}$ $=0.34, \mathrm{p}=0.80)$ and $0.2 \mu \mathrm{gl}^{-1}(1-$ way ANOVA, $\left.F_{3,15}=1.1, \mathrm{p}=0.40\right) \mathrm{Zn}$ was added (Fig. 3b); however, fertilization was $43.7 \%$ lower at $400 \mu \mathrm{atm}$ $\mathrm{pCO}_{2}$ than at $1500 \mu \mathrm{atm}$ when $1 \mu \mathrm{g}$ $\mathrm{ml}^{-1} \mathrm{Zn}$ was added (SNK, $\mathrm{p}<0.001$; Fig. 3b).

There were also interactive effects of $\mathrm{pCO}_{2}$ and metals on egg diameter in abalone (Table 2). $\mathrm{Cu}$ addition caused a significant egg diameter in- 
(a)

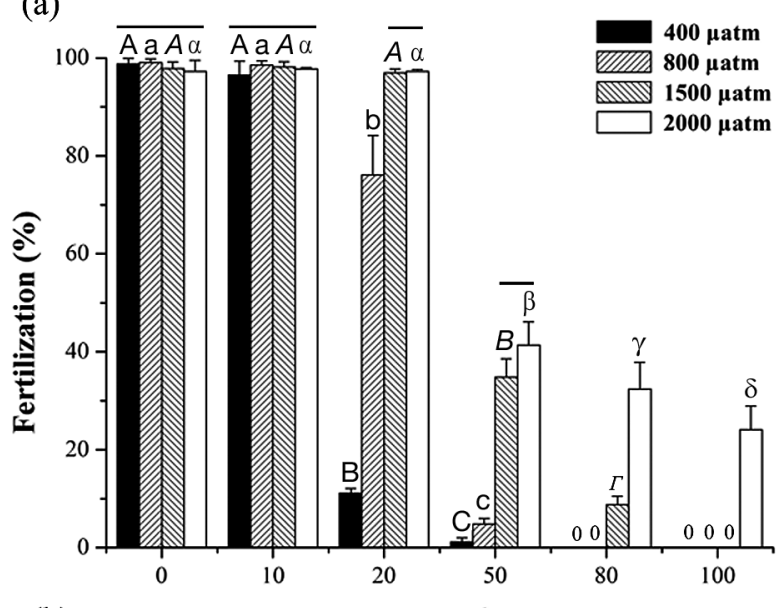

(b)

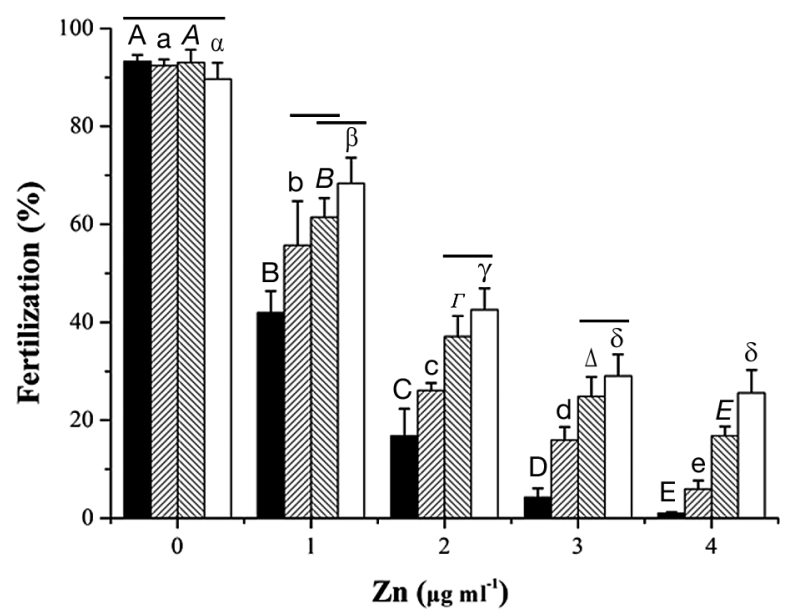

Fig. 2. Fertilization rate (mean $+\mathrm{SD}, \mathrm{n}=4$ ) of Crassostrea angulata $2 \mathrm{~h}$ post fertilization at 4 levels of $\mathrm{pCO}_{2}$ with the addition of (a) Cu or (b) Zn. Different upper- and lowercase letters represent significant differences between trace metal concentrations at the same $\mathrm{pCO}_{2}$ level $(\mathrm{p}<0.05)$. A line above columns indicates no significant difference across $\mathrm{pCO}_{2}$ levels at the same trace metal concentrations. Columns not connected by lines are significantly different from each other $(p<0.05)$

crease at a $\mathrm{pCO}_{2}$ level of $400 \mu \mathrm{atm}$, yet this effect decreased as $\mathrm{pCO}_{2}$ increased. For example, at $400 \mu \mathrm{atm}$, egg diameter increased by $11.2 \%$ when $150 \mu \mathrm{g} \mathrm{l}^{-1} \mathrm{Cu}$ was added (SNK, p < 0.001; Fig. 4a); however, at $1500 \mu \mathrm{atm}$, there was no significant difference in egg diameter between the 0 and $150 \mu \mathrm{g} \mathrm{l}^{-1} \mathrm{Cu}$ treatments $(\mathrm{SNK}, \mathrm{p}=0.16$; Fig. $4 \mathrm{a})$. Similarly, the average egg diameter increased by $37.8 \%$ when $300 \mu \mathrm{g} \mathrm{l}^{-1} \mathrm{Cu}$ was added at 400 ratm, but by only $11.6 \%$ at 1500 ratm (Fig. 4c). Zn addition had no effect on egg diameter at $400 \mu \mathrm{atm}\left(1\right.$-way ANOVA, $F_{2,11}=3.9, \mathrm{p}=$ $0.061)$; however, egg diameter decreased significantly when $\mathrm{Zn}$ was added at 1500 ratm (e.g. a $2.5 \%$ reduction in diameter with the addition of $1 \mu \mathrm{g} \mathrm{ml}^{-1}$ Zn: SNK, p $<0.001$; Fig. 4b,d). (a)

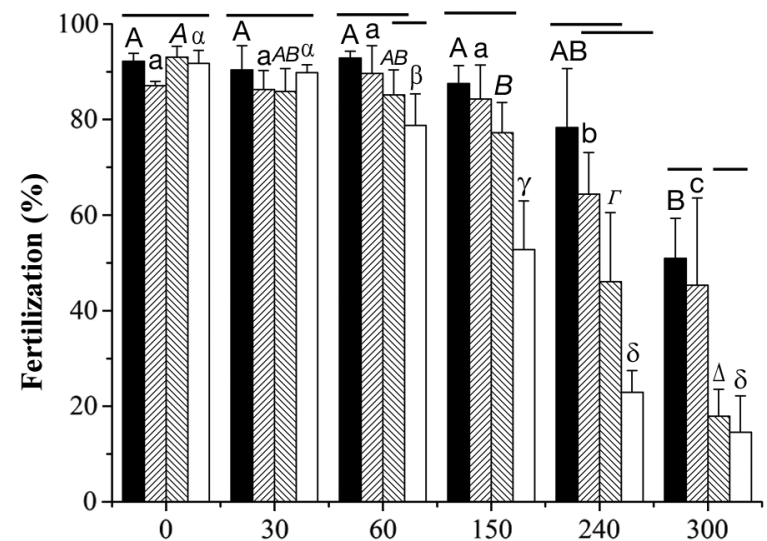

(b)

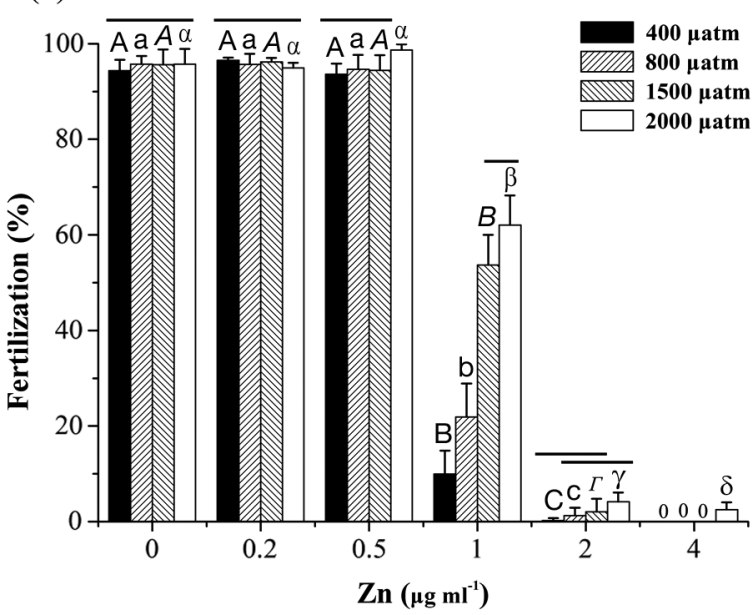

Fig. 3. Fertilization rate (mean $+\mathrm{SD}, \mathrm{n}=4$ ) of Haliotis discus hannai $2 \mathrm{~h}$ post fertilization at 4 levels of $\mathrm{pCO}_{2}$ with the addition of (a) Cu or (b) Zn. Different upper- and lowercase letters represent significant differences between trace metal concentrations at the same $\mathrm{pCO}_{2}$ level $(\mathrm{p}<0.05)$. A line above columns indicates no significant difference across $\mathrm{pCO}_{2}$ levels at the same trace metal concentrations. Columns not connected by lines are significantly different from each other $(p<0.05)$

\subsection{Combined effects of $\mathrm{OA}$ and trace metals on larval deformation of $C$. angulata}

A significant interaction between the effects of $\mathrm{OA}$ and $\mathrm{Cu}$ on larval deformation in $C$. angulata was observed (2-way ANOVA, $F_{4,27}=111.4, \mathrm{p}<$ 0.001; Table 2). For example, the larval deformation rate increased by $7.7 \%$ between the no $\mathrm{Cu}$ and $5 \mu \mathrm{g}$ $\mathrm{I}^{-1} \mathrm{Cu}$ treatments at $400 \mu \mathrm{atm}(\mathrm{SNK}, \mathrm{p}<0.001$; Fig. 5a), but by $22.0 \%$ at $800 \mu$ atm (SNK, p $<0.001$; Fig. 5a). Thus, OA increased Cu toxicity to oyster larval development.

In contrast, there was no interaction between the effects OA and $\mathrm{Zn}$ in larval deformation of $C$. angu- 
(a)

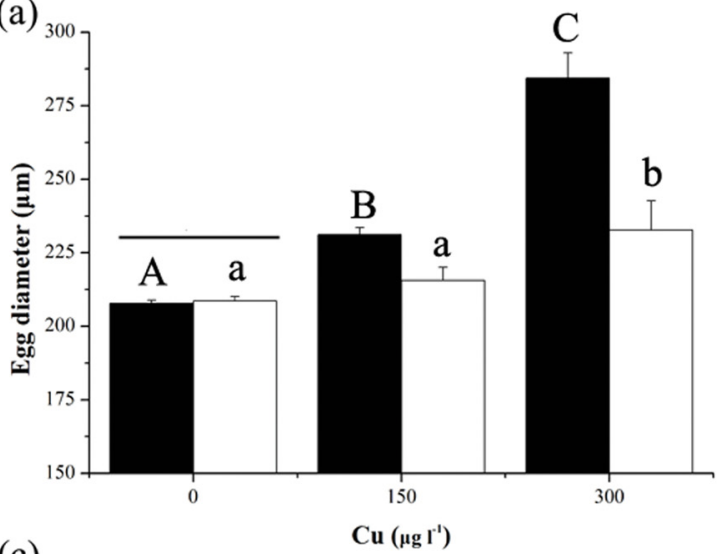

(c)

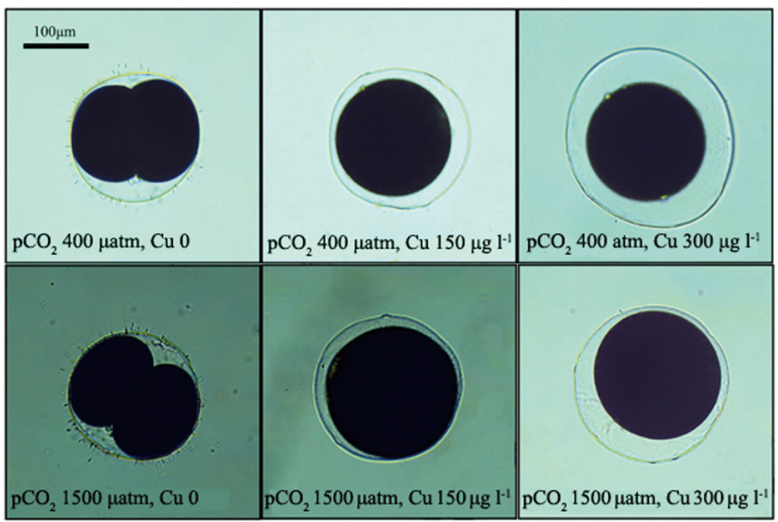

(b)

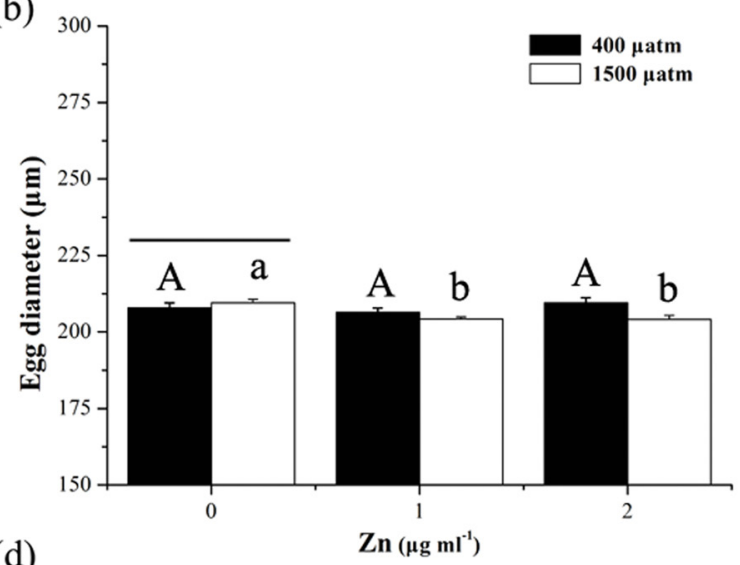

(d)

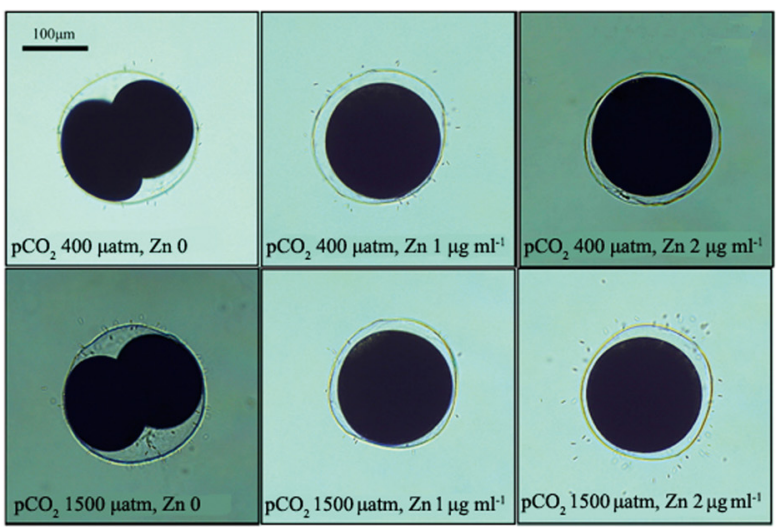

Fig. 4. Egg diameter (mean $+\mathrm{SD}_{;} \mathrm{n}=4$ ) of Haliotis discus hannai $2 \mathrm{~h}$ post fertilization at $\mathrm{pCO}_{2} 400$ and $1500 \mu$ atm with the addition of (a) $\mathrm{Cu}$ or (b) $\mathrm{Zn}$. Different upper- and lowercase letters represent significant differences between different trace metal concentrations at the same $\mathrm{pCO}_{2}$ level $(\mathrm{p}<0.05)$. A line above columns indicates no significant difference between 400 and $1500 \mu \mathrm{atm}$ at the same trace metal concentration. Columns not connected by lines are significantly different from each other $(\mathrm{p}<0.05)$. Photos showing (c) significant expansion of egg membrane in high Cu concentration treatments at $\mathrm{pCO}_{2} 400 \mu \mathrm{atm}$ but less evident expansion at $\mathrm{pCO}_{2} 1500 \mu \mathrm{atm}$, and (d) subtle but significant reduction of egg diameter in high Zn concentration treatments at $\mathrm{pCO}_{2} 1500 \mu \mathrm{atm}$

lata (2-way ANOVA, $F_{4,27}=2.7, \mathrm{p}=0.051$; Table 2, Fig. 5b).

\subsection{Combined effects of $O A$ and trace metals on larval deformation of $\boldsymbol{H}$. discus hannai}

A significant interaction between the effects of OA and $\mathrm{Cu}$ on larval deformation in $H$. discus hannai was detected (2-way ANOVA, $F_{4,36}=48.9$, p $<0.001$; Table 2). For example, larval deformation increased by $10.7 \%$ between the no $\mathrm{Cu}$ and $5 \mu \mathrm{g} \mathrm{l}^{-1} \mathrm{Cu}$ treatments at 400 patm (SNK, p =0.001; Fig. 6a), but by $71.4 \%$ at $1500 \mu \mathrm{atm}$ (SNK, p < 0.001; Fig. 6a). OA thus increased $\mathrm{Cu}$ toxicity to abalone larval development.

An interaction also existed between the effects of OA and Zn on larval deformation of $H$. discus hannai (2-way ANOVA, $F_{6,36}=40.0, \mathrm{p}<0.001$; Table 2). For example, at 400 patm, larval deformation increased by $31.5 \%$ when $60 \mu \mathrm{g} \mathrm{l^{-1 }} \mathrm{Zn}$ was added (KW, p = 0.032; Fig. 6b); however, at 1500 patm, deformation increased by $37.2 \%$ when only $20 \mu \mathrm{g} \mathrm{l}^{-1} \mathrm{Zn}$ was added (SNK, p < 0.001; Fig. 6b). OA increased Zn toxicity to abalone larval development.

\subsection{Combined effects of $\mathrm{OA}$ and trace metals on larval shell length of $C$. angulata}

$\mathrm{OA}$ and $\mathrm{Cu}$ had no interactive effects on larval shell length in $C$. angulata (2-way ANOVA, $F_{4,27}=$ 2.1, p = 0.11; Table 2, Fig. 7a). However, an interaction existed between the effects of OA and $\mathrm{Zn}$ on shell length (2-way ANOVA, $F_{4,27}=3.7, \mathrm{p}=0.015$; Table 2). For example, shell length was reduced by $3.1 \%$ between 0 and $25 \mu \mathrm{g} \mathrm{l}^{-1} \mathrm{Zn}$ at $400 \mu \mathrm{atm}$ (SNK, 

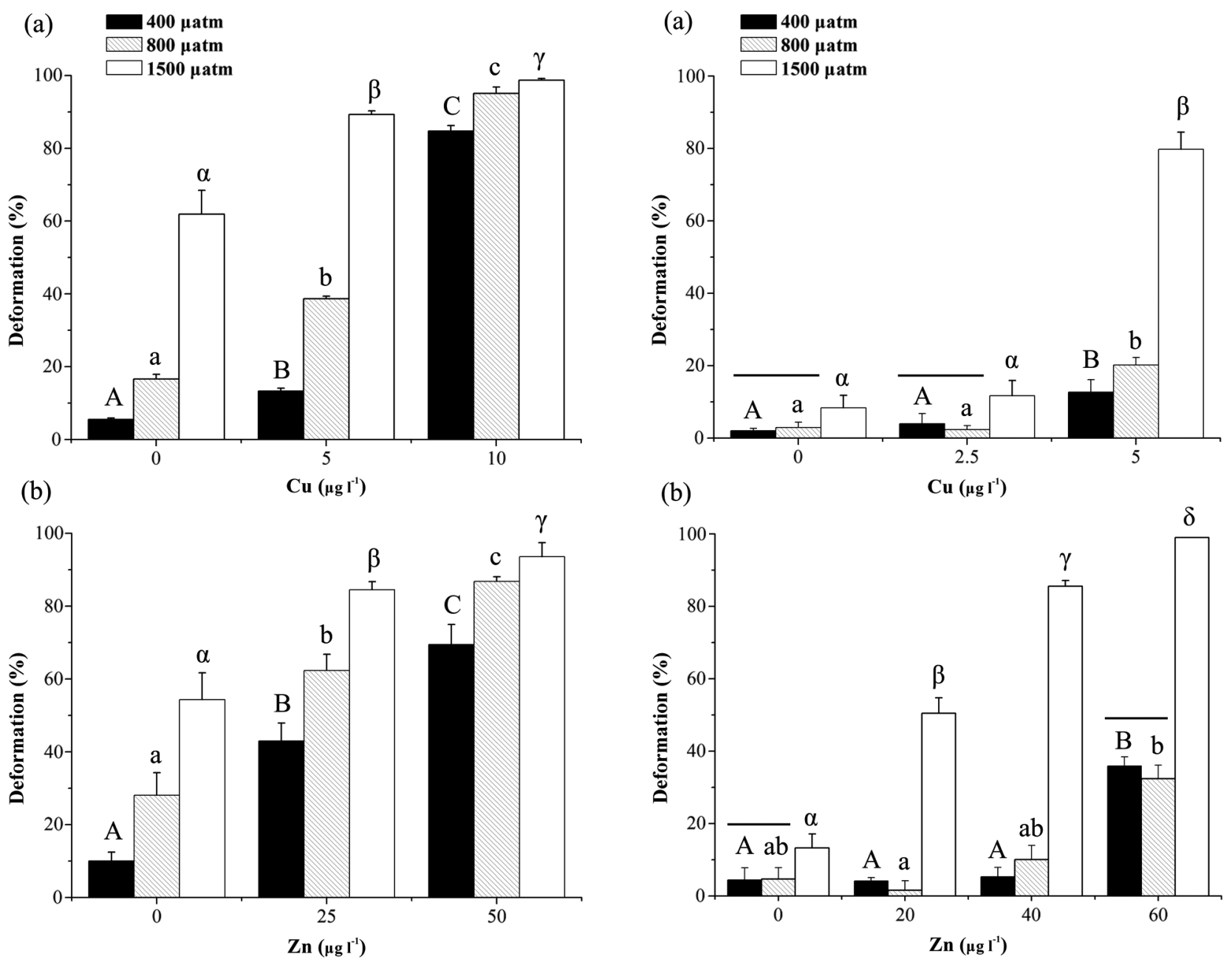

Fig. 5. Deformation rate (mean $+\mathrm{SD}_{i} \mathrm{n}=4$ ) of Crassostrea angulata larvae $24 \mathrm{~h}$ post fertilization at $3 \mathrm{pCO}_{2}$ levels with the addition of (a) $\mathrm{Cu}$ or (b) $\mathrm{Zn}$. Different upper- and lowercase letters represent significant differences between trace metal concentrations at the same $\mathrm{pCO}_{2}$ level $(\mathrm{p}<0.05)$. A line above columns indicates no significant difference between $\mathrm{pCO}_{2}$ levels at the same trace metal concentration. Columns not connected by lines are significantly different from each other $(\mathrm{p}<0.05)$

p $<0.001$; Fig. 7b), but only by $1.5 \%$ at $800 \mu$ atm (SNK, p $<0.001$; Fig. 7b). Overall, OA alleviated Zn inhibition of oyster larval calcification.

\subsection{Combined effects of $\mathrm{OA}$ and trace metals on larval shell length of $\boldsymbol{H}$. discus hannai}

There was an interaction between the effects of OA and $\mathrm{Cu}$ on larval shell length in $H$. discus hannai (2way ANOVA, $F_{4,27}=11.7, \mathrm{p}<0.001$; Table 2). For example, shell length did not change with rising $\mathrm{Cu}$ concentration at $400 \mu$ atm (1-way ANOVA, $F_{2,11}=$

Fig. 6. Deformation rate (mean $+\mathrm{SD}_{;} \mathrm{n}=4$ ) of Haliotis discus hannai larvae $24 \mathrm{~h}$ post fertilization at $3 \mathrm{pCO}_{2}$ levels with the addition of (a) $\mathrm{Cu}$ or (b) Zn. Different upper- and lowercase letters represent significant differences between trace metal concentrations at the same $\mathrm{pCO}_{2}$ level $(\mathrm{p}<0.05)$. A line above columns indicates no significant difference between $\mathrm{pCO}_{2}$ levels at the same trace metal concentration. Columns not connected by lines are significantly different from each other $(\mathrm{p}<0.05)$

0.21, $\mathrm{p}=0.82 ;$ Fig. 8a) and 800 patm (1-way ANOVA, $F_{2,11}=1.9, p=0.20$; Fig. 8a). However, at $1500 \mu$ atm, shell length was reduced by $8.8 \%$ when $5 \mu \mathrm{g} \mathrm{l}^{-1} \mathrm{Cu}$ was added (SNK, p = 0.001, Fig. 8a).

An interaction also existed between the effects of $\mathrm{OA}$ and $\mathrm{Zn}$ on shell length in $H$. discus hannai (2-way ANOVA, $F_{6,36}=28.9, \mathrm{p}<0.001$; Table 2). For example, at 400 and $800 \mu a t m$, shell length decreased by $8.1 \%$ (SNK, p < 0.001, Fig. 8b) and 6.6\% (SNK, p < 0.001, Fig. 8b) respectively when $60 \mu \mathrm{g} \mathrm{l}^{-1} \mathrm{Zn}$ was added. However, at $1500 \mu \mathrm{atm}$, shell length was reduced by $8.6 \%$ when only $20 \mu \mathrm{g} \mathrm{l}^{-1} \mathrm{Zn}$ was added (SNK, p $<0.001$, Fig. 8b). 
(a)

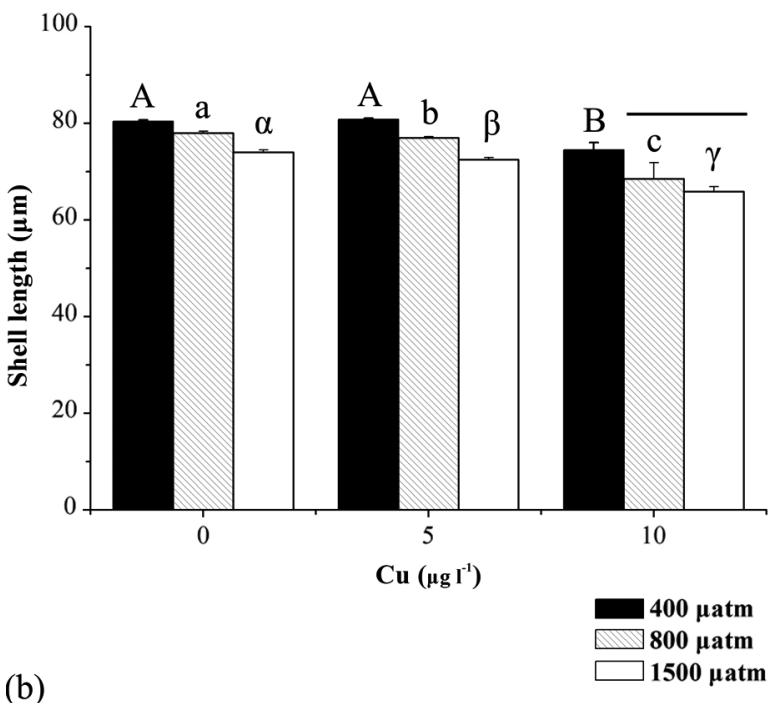

(b)

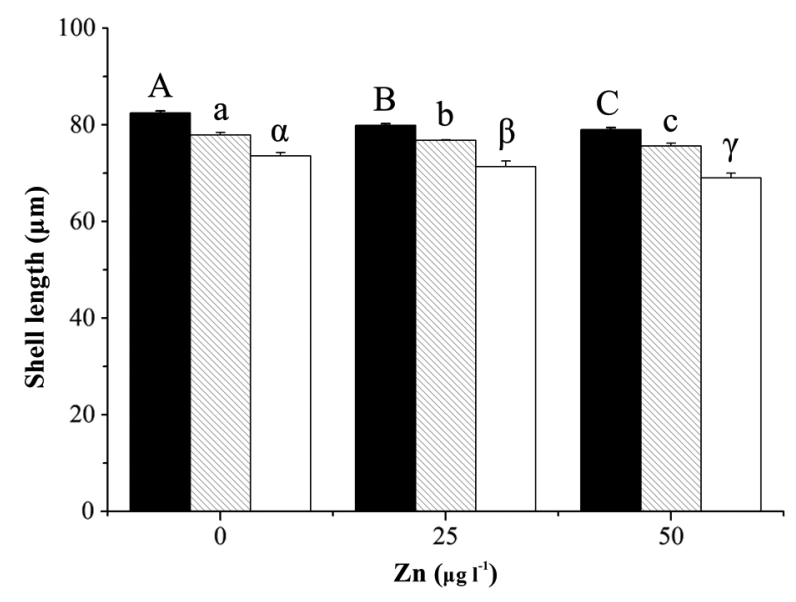

Fig. 7. Shell length (mean $+\mathrm{SD}_{;} \mathrm{n}=4$ ) of Crassostrea angulata larvae $24 \mathrm{~h}$ post fertilization at $3 \mathrm{pCO}_{2}$ levels with the addition of (a) $\mathrm{Cu}$ or (b) Zn. Different upper- and lowercase letters represent significant differences between trace metal concentrations at the same $\mathrm{pCO}_{2}$ level $(\mathrm{p}<0.05)$. A line above columns indicates no significant difference between $\mathrm{pCO}_{2}$ levels at the same trace metal concentration. Columns not connected by lines are significantly different from each other $(\mathrm{p}<0.05)$

\section{DISCUSSION}

Inhibition of fertilization under high- $\mathrm{pCO}_{2}$ conditions occurs in different marine invertebrates (Morita et al. 2010, Moulin et al. 2011, Reuter et al. 2011, Barros et al. 2013, Foo et al. 2014). In the marine bivalve Tegillarca granosa, sperm motility, gamete fusion and ovular calcium oscillation in fertilization were all impeded by OA (Shi et al. 2017). Respiration of sperm was inhibited in the mussel Mytilus edulis at $\mathrm{pH}<7.5$ (Akberali et al. 1985). Similarly, the mitochondrial membrane potential (MMP) in sperm of the sea (a)
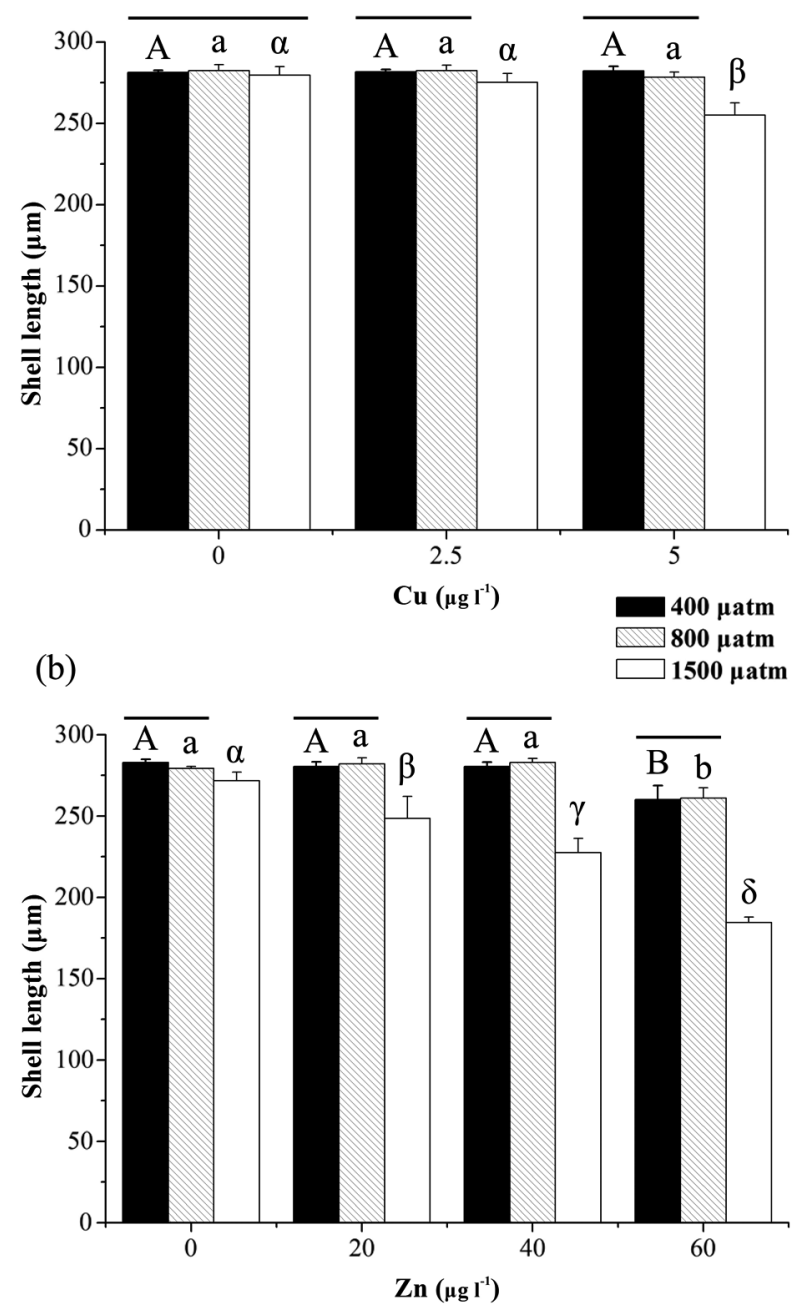

Fig. 8. Shell length (mean $+\mathrm{SD} ; \mathrm{n}=4$ ) of Haliotis discus hannai larvae $24 \mathrm{~h}$ post fertilization at $3 \mathrm{pCO}_{2}$ levels with the addition of (a) Cu or (b) Zn. Different upper- and lowercase letters represent significant differences between trace metal concentrations at the same $\mathrm{pCO}_{2}$ level $(\mathrm{p}<0.05)$. A line above columns indicates no significant difference between $\mathrm{pCO}_{2}$ levels at the same trace metal concentration. Columns not connected by lines are significantly different from each other $(\mathrm{p}<0.05)$

urchin Centrostephanus rodgersii was significantly reduced under OA conditions ( $\mathrm{pH}$ reduced by 0.3 and 0.5 ; Schlegel et al. 2015). The main energy source for motility in sperm is mitochondrial respiration, for which MMP can be used as a proxy; sperm in ambient seawater usually have a higher MMP than sperm in high- $\mathrm{pCO}_{2}$ seawater. Consequently, the reduced motility of sperm under OA conditions could be the result of inhibited respiration. The acrosome reaction and ovular calcium oscillation are crucial processes for gamete fusion and embryo development respectively, and both require an influx of cal- 
cium into gametes. Since OA may lead to reduced intracellular pH (Gibbin et al. 2014), which prevents calcium uptake by the cell from seawater (Thomas \& Meech 1982), the overall result may be failure of both the acrosome reaction and embryo cleavage.

Adverse effects of $\mathrm{Cu}$ and $\mathrm{Zn}$ on fertilization have often been reported (Reichelt-Brushett \& Harrison 1999, Reichelt-Brushett \& Michalek-Wagner 2005, Victor \& Richmond 2005). $\mathrm{Cu}^{2+}$ is reduced to $\mathrm{Cu}^{+}$after entering the cell, which binds with sulfhydryl groups (Viarengo et al. 1996) of enzymes in the electron transport chain (Ay et al. 1999). This can inhibit the ATP production of sperm and affect sperm motility. $\mathrm{Cu}$ accumulation in sperm mitochondria can decrease MMP and cause formation of reactive oxygen species (ROS), leading to oxidative damage (Krumschnabel et al. 2005). Similarly, ROS production is the main toxic effect caused by $\mathrm{Zn}$, which has been observed in many species, including bivalves (Geret \& Bebianno 2004). Trace metals may also induce the release of free calcium in eggs from intracellular calcium stores such as the endoplasmic reticulum, causing an increase of intracellular calcium concentration. Fertilized eggs of the sea urchin Psammechinus miliaris treated with $\mathrm{Cu}$ exhibited a significantly higher free calcium signal than control, untreated eggs (Schäfer et al. 2009). However, the abnormally high calcium concentration significantly inhibited fertilization because degradative enzymes that depended on excess calcium were activated, which compromised mitochondrial function and cytoskeletal organization, and ultimately resulted in developmental failure.

In contrast, $\mathrm{Cu}$ and $\mathrm{Zn}$ may also have positive effects on molluscan reproduction, e.g. by increasing the ionic permeability of organelle membranes. A significant decrease in calcium level was found in the acrosomes and mitochondria of $M$. edulis sperm after $\mathrm{Cu}$ and $\mathrm{Zn}$ exposure (Earnshaw et al. 1986). Both metals can induce the release of pre-loaded calcium from the matrix of $M$. edulis mitochondria, with $\mathrm{Cu}$ being more effective at this than Zn (Akberali \& Earnshaw 1982). The result of this induction could be an increase in the concentration of free calcium in sperm cytoplasm. As intracellular free calcium plays an important role in activating sperm, $\mathrm{Cu}$ and $\mathrm{Zn}$ may cause an increase in sperm mobility. Likewise, exposure to $\mathrm{Cu}$ stimulated the respiration of unfertilized eggs of $M$. edulis, which was attributed to enhanced potassium influx and uncoupling of oxidative phosphorylation induced by $\mathrm{Cu}$ (Akberali et al. 1984). Considering respiration of fertilized eggs continues to increase throughout embryonic development, stimulation of respiration by $\mathrm{Cu}$ may benefit the develop- ment of molluscan embryos. Consequently, the effects of $\mathrm{Cu}$ and $\mathrm{Zn}$ on gametes of marine invertebrates are complex: toxicity to enzymes, production of ROS and excess calcium intake could hamper fertilization, while enhanced gamete respiration could benefit fertilization and embryonic development. Final effects of the 2 metals are likely exposure-dependent, both in terms of duration and concentration.

Under the combined $\mathrm{OA}$ and addition of $\mathrm{Cu}$ or $\mathrm{Zn}$, metal ions promote calcium influx into the gametes, which could increase sperm velocity, stimulate the acrosomal reaction and also compensate for the insufficient uptake of calcium during fertilization caused by OA. These processes could reduce the adverse effects caused by OA and metals independently, which may be the reason for the antagonistic interaction between the effects of $\mathrm{OA}$ and $\mathrm{Cu}$ or $\mathrm{Zn}$ on fertilization seen in the present study. An alternative explanation is the competition between protons and metal ions for binding sites on the cell surface (Kerndorff \& Schnitzer 1980, Schubauer-Berigan et al. 1993). When $\mathrm{pCO}_{2}$ increases (inducing a higher seawater proton concentration), excess protons may bind to the sperm cell surface, increasing the positive charge on the outer cell membrane and inhibiting the entry of positively charged metal ions. Thus, low $\mathrm{pH}$ may represent a protection mechanism for invertebrate reproduction in metal-polluted sites.

In contrast to the antagonistic interaction observed in the combined treatments of OA and metals on oyster fertilization in the present study, rising $\mathrm{pCO}_{2}$ could increase the toxicity of $\mathrm{Cu}$ to abalone fertilization, and this may be attributed to the structure of the abalone egg. Abalone eggs differ from those of oysters in that they are covered with an egg jelly coat and vitelline envelope, with the vitelline envelope beneath the jelly coat. The thickness of the egg jelly varies from 30 to $100 \mu \mathrm{m}$ for different abalone species, while the vitelline envelope is thin (about $1 \mu \mathrm{m}$ ). The egg jelly of abalone Haliotis asinina mainly contains 2 glycoproteins at $107 \mathrm{kDa}$ and $178 \mathrm{kDa}$, with glucose as the major sugar component, and the vitelline envelope also contains the 2 glycoproteins (Suphamungmee et al. 2010). The role of the egg jelly glycoproteins is to accelerate sperm motility (Suphamungmee et al. 2010), and the vitelline envelope binds with sperm and triggers the acrosome reaction (Vacquier et al. 1999).

Influence of metal ions on the egg jelly and vitelline envelope of marine invertebrates has not been documented. However, a study on the plant cell wall led to the hypothesis that $\mathrm{Cu}^{2+}$ could be reduced to $\mathrm{Cu}^{+}$ by apoplastic electron donors when it complexes with cell wall glycoproteins and that the $\mathrm{Cu}^{+}$can 
then undergo a Fenton reaction with apoplastic hydrogen peroxide $\left(\mathrm{H}_{2} \mathrm{O}_{2}\right)$ to generate hydroxyl radicals $(\cdot \mathrm{OH})$ (Fry et al. 2002). These radicals can cause non-enzymic scission of wall polysaccharides and may loosen the cell wall. Considering the high oxidative capacity of $\cdot \mathrm{OH}$, the structure of the glycoproteins in the egg jelly and vitelline envelope could also be comprised under $\mathrm{Cu}$ exposure. Thus, both the egg jelly and the vitelline envelope may lose their integrity due to structural destruction, causing the vitelline envelope to expand, as indicated by the significant increase of egg diameter seen in our experiments. Fertilization success could be improved as a result of the larger surface area for sperm to come in contact with, thus increasing the chance that a sperm cell enters the egg. In other words, Cu may not only be toxic but may also promote abalone fertilization under ambient $\mathrm{pCO}_{2}$ conditions. Thus, a nearly $50 \%$ fertilization rate was maintained in abalone at ambient $\mathrm{pCO}_{2}$ when as much as $300 \mu \mathrm{g} \mathrm{l^{-1 }} \mathrm{Cu}$ was added, compared with no fertilization in oysters (where egg diameter was not affected) under a $\mathrm{Cu}$ addition of $100 \mu \mathrm{g} \mathrm{l}^{-1}$ at ambient $\mathrm{pCO}_{2}$. In seawater with higher $\mathrm{pCO}_{2}$, expansion of the egg membrane was significantly inhibited; therefore, the toxicity of $\mathrm{Cu}$ played a more important role. In other words, $\mathrm{Cu}$ toxicity to abalone fertilization was enhanced by OA. The subtle but significant reduction of abalone egg diameter under combined treatments of high $\mathrm{pCO}_{2}$ and $\mathrm{Zn}$ addition also indicated that $\mathrm{Zn}$ ions might alter egg structure at higher $\mathrm{pCO}_{2}$. Further studies are needed to reveal the mechanism of the combined effects of $\mathrm{OA}$ and metal ions on abalone egg structure.

$\mathrm{Cu}$ addition at high- $\mathrm{pCO}_{2}$ levels significantly increased larval deformation in oysters in our study. Strong interactions between $\mathrm{pCO}_{2}$ and $\mathrm{Cu}$ were also found by Lewis et al. (2013), where very high polychaete larval mortality occurred at low $\mathrm{pH}$ with $\mathrm{Cu}$ addition compared to low $\mathrm{pH}$ without $\mathrm{Cu}$. This synergistic effect may be attributed to an increase of free $\mathrm{Cu}$ and $\mathrm{Zn}$ ions under OA, as predicted by Millero et al. (2009). Such a phenomenon was observed by Shi et al. (2016), who found that the ratio of $\mathrm{Cd}^{2+}$ to $\mathrm{Ca}^{2+}$ was significantly increased in high $\mathrm{pCO}_{2}$ seawater. In addition, OA could reduce larval metabolic rate, so that the energy supply may become insufficient for larvae to expel trace metals extracellularly. Although OA temporarily inhibits metal ions from penetrating the embryo at the fertilization stage through higher proton concentration, it is highly likely that the metals could still accumulate inside the cell over longer exposure. A recent study found that $\mathrm{Cu}$ accumulation was significantly higher in adult oysters exposed to
$\mathrm{Cu}$ for $28 \mathrm{~d}$ at $\mathrm{pH} 7.6$ than in exposed individuals at pH 8.1 and 7.8 (Cao et al. 2019). Metallothionein (MT) plays an important part in the detoxification of many trace metals in molluscs, and transcription of MT-mRNA can be rapidly activated under metal exposure, leading to increased synthesis of MT which in turn binds metal ions (Isani et al. 2000). However, molluscan embryos might be relatively weak in dealing with metal toxicity. The oyster Crassostrea virginica was unable to produce metallothionein before 8 hpf (Roesijadi et al. 1996), and MT-mRNA expression was limited in the larval stage compared to adults (Unger \& Roesijadi 1996). Consequently, higher metal accumulation induced by $\mathrm{OA}$ and limited detoxification ability during the larval stage could be the reasons for the synergistic effect of OA and metals on larval deformation.

Both $\mathrm{Cu}$ and $\mathrm{Zn}$ could adversely affect larval shell formation. $\mathrm{Cu}$ inhibits the activity of carbonic anhydrase (Vitale et al. 1999), a key enzyme in organism calcification, thus reducing shell growth. Decreased shell growth under Zn exposure might be caused by its competitive binding with calcium receptors when the shell is forming, as the $\mathrm{Zn}$ and $\mathrm{Ca}$ ions have similar atomic diameters and are both divalent ions. OA could also modulate gene expression of carbonic anhydrase. Todgham \& Hofmann (2009) found an upregulation of the carbonic anhydrase gene under high $\mathrm{pCO}_{2}$, while Stumpp et al. (2011) reported a downward regulation in echinoderm larvae. Suppression of gene expression of carbonic anhydrase was also discovered in larvae of oysters C. gigas under high $\mathrm{pCO}_{2}$ (De Wit et al. 2018). In the present study, the inhibition of abalone larval calcification induced by $\mathrm{Cu}$ and $\mathrm{Zn}$ was enhanced under OA conditions. OA may have inhibited carbonic anhydrase synthesis in abalone larvae so that more energy was diverted to detoxification of metals. Therefore, the energy was insufficient to sustain normal calcification, and larval shell growth was even more reduced when OA and metals co-occurred. In contrast to abalone, oyster larvae might allocate more energy to maintaining shell growth, and that is why their larval shell growth was not further inhibited under the combined treatment of $\mathrm{OA}$ and $\mathrm{Cu}$. $\mathrm{Zn}$ ions are cofactors of carbonic anhydrase, and $\mathrm{Zn}$ addition might therefore induce the up-regulation of the carbonic anhydrase gene, therefore alleviating inhibition of larval shell growth caused by OA.

Acclimation to environmental changes can be assessed in transgenerational investigations. Exposing adult Sydney rock oysters Saccostrea glomerata to high $\mathrm{pCO}_{2}$ conditions induced parental carryover ef- 
fects in the next-generation larvae (Parker et al. 2012). Larvae from oysters undergoing conditioning within elevated $\mathrm{pCO}_{2}$ environments grew faster and larger than larvae produced by adults raised in ambient $\mathrm{pCO}_{2}$. Mussel M. edulis larvae originating from high $\mathrm{pCO}_{2}$ environments exhibited increased tolerance to acidified environments (Thomsen et al. 2017). In another study on $M$. edulis, transgenerational exposure to high $\mathrm{pCO}_{2}$ conditions induced the offspring to precipitate calcite - which is a less soluble form of calcium carbonate - instead of aragonite in their shells (Fitzer et al. 2014). Therefore, molluscs likely become tolerant to OA after long term and transgenerational exposure to low $\mathrm{pH}$ conditions. Our study species vary in their likelihood to adapt to OA. C. angulata is an estuarine intertidal species that lives in environments with large fluctuations in $\mathrm{pH}$ and trace metal concentrations, and has adapted to the unstable environmental conditions over generations of acclimation. Abalone $H$. discus hannai inhabit environmentally stable offshore regions and are thus more susceptible to a changing environment. This may be the reason why our results show $C$. angulata to be more tolerant to the combined effects of OA and metals than $H$. discus hannai. The larval stage is very important for population sustainability of molluscs, and impaired larvae would no doubt reduce the yield of molluscan aquaculture. It is very likely that culture of $H$. discus hannai would be threatened under the concurrence of $\mathrm{OA}$ and trace metal pollution at aquaculture sites. Larvae of $C$. angulata seem more resistant to OA and metal in their early developmental stage; however, chronic effects could emerge under longer exposure (e.g. during the entire larval stage or even to the adult stage). Therefore, culture of $C$. angulata could also be adversely affected by combined exposure to OA and metals at oyster farms.

In conclusion, this study has provided evidence that variation in $\mathrm{pCO}_{2}$ levels, developmental stages, egg structure and species can all affect metal toxicity to the early development of molluscs. Future research should include additional parameters such as other environmental stressors, developmental stages and gamete properties of the tested organisms when assessing metal toxicity to molluscan embryos. Further biochemical and physiological studies are needed to clarify the biological mechanisms of the combined effects of OA and trace metals on molluscan embryonic and larval development. Based on the results of the present study, we propose that the production yield of molluscan aquaculture will decrease at metal polluted sites when seawater becomes more acidic as predicted by climate change models.
Acknowledgements. This study was funded by NSFC (No. 31672651, No. 41176113), Major Science and Technology Projects in Fujian Province (2016NZ0001-4), the Earmarked Fund for Modern Agro-industry Technology Research System (No. CARS-49) and the Quanzhou City Science \& Technology Program of China (2018N006).

\section{LITERATURE CITED}

Akberali HB, Earnshaw MJ (1982) A possible role for mitochondrial calcium in the contraction of the mollusc siphon induced by copper. Comp Biochem Physiol C Comp Pharmacol 73:395-398

Akberali HB, Earnshaw MJ, Marriott KR (1984) The action of heavy metals on the gametes of the marine mussel, Mytilus edulis (L.) - I. Copper-induced uncoupling of respiration in the unfertilized egg. Comp Biochem Physiol C Comp Pharmacol 77:289-294

Akberali HB, Earnshaw MJ, Marriott KRM (1985) The action of heavy metals on the gametes of the marine mussel, Mytilus edulis (L.) - II. Uptake of copper and zinc and their effect on respiration in the sperm and unfertilized egg. Mar Environ Res 16:37-59

Ay O, Kalay M, Tamer L, Canli M (1999) Copper and lead accumulation in tissues of a freshwater fish Tilapia zillii and its effects on the branchial $\mathrm{Na}$, K-ATPase activity. Bull Environ Contam Toxicol 62:160-168

* Barros P, Sobral P, Range P, Chicharo L, Matias D (2013) Effects of seawater acidification on fertilization and larval development of the oyster Crassostrea gigas. J Exp Mar Biol Ecol 440:200-206

* Belivermiş M, Warnau M, Metian M, Oberhänsli F, Teyssié JL, Lacoue-Labarthe T (2016) Limited effects of increased $\mathrm{CO}_{2}$ and temperature on metal and radionuclide bioaccumulation in a sessile invertebrate, the oyster Crassostrea gigas. ICES J Mar Sci 73:753-763

Byrne M (2010) Impact of climate change stressors on marine invertebrate life histories with a focus on the Mollusca and Echinodermata. In: Yu J, Henderson-Sellers A (eds) Climate alert: climate change monitoring and strategy. University of Sydney Press, Sydney, p 142-185

Byrne M (2011) Impact of ocean warming and ocean acidification on marine invertebrate life history stages: vulnerabilities and potential for persistence in a changing ocean. Oceanogr Mar Biol Annu Rev 49:1-42

Byrne M (2012) Global change ecotoxicology: identification of early life history bottlenecks in marine invertebrates, variable species responses and variable experimental approaches. Mar Environ Res 76:3-15

Cai WJ, Wang Y (1998) The chemistry, fluxes, and sources of carbon dioxide in the estuarine waters of the Satilla and Altamaha Rivers, Georgia. Limnol Oceanogr 43: 657-668

Cai WJ, Hu XP, Huang WJ, Murrell MC and others (2011) Acidification of subsurface coastal waters enhanced by eutrophication. Nat Geosci 4:766-770

Calabrese A, MacInnes JR, Nelson DA, Miller JE (1977) Survival and growth of bivalve larvae under heavy-metal stress. Mar Biol 41:179-184

Cao R, Zhang T, Li X, Zhao Y and others (2019) Seawater acidification increases copper toxicity: a multi-biomarker approach with a key marine invertebrate, the Pacific oyster Crassostrea gigas. Aquat Toxicol 210:167-178

Dailianis S, Piperakis SM, Kaloyianni M (2005) Cadmium effects on ROS production and DNA damage via adrenergic receptors stimulation: role of $\mathrm{Na}^{+} / \mathrm{H}^{+}$exchanger 
and PKC. Free Radic Res 39:1059-1070

Dame RF (1996) Ecology of marine bivalves: an ecosystem approach. CRC Press, Boca Raton, FL

Dame RD, Libes S (1993) Oyster reefs and nutrient retention in tidal creeks. J Exp Mar Biol Ecol 171:251-258

* Dame RD, Spurrier JD, Wolaver TG (1989) Carbon, nitrogen and phosphorus processing by an oyster reef. Mar Ecol Prog Ser 54:249-256

De Wit P, Durland E, Ventura A, Langdon CJ (2018) Gene expression correlated with delay in shell formation in larval Pacific oysters (Crassostrea gigas) exposed to experimental ocean acidification provides insights into shell formation mechanisms. BMC Genomics 19:160

Wupont S, Ortega-Martinez O, Thorndyke M (2010) Impact of near-future ocean acidification on echinoderms. Ecotoxicology 19:449-462

Earnshaw MJ, Wilson S, Akberali HB, Butlera RD, Marriott KRM (1986) The action of heavy metals on the gametes of the marine mussel, Mytilus edulis (L.) - III. The effect of applied copper and zinc on sperm motility in relation to ultrastructural damage and intracellular metal localization. Mar Environ Res 20:261-278

Fitzer SC, Caldwell GS, Clare AS, Upstill-Goddard RC, Bentley MG (2013) Response of copepods to elevated $\mathrm{pCO}_{2}$ and environmental copper as co-stressors - a multigenerational study. PLOS ONE 8:e71257

Fitzer SC, Cusack M, Phoenix VR, Kamenos NA (2014) Ocean acidification reduces the crystallographic control in juvenile mussel shells. J Struct Biol 188:39-45

Foo SA, Dworjanyn SA, Khatkar MS, Poore AGB, Byrne M (2014) Increased temperature, but not acidification, enhances fertilization and development in a tropical urchin: potential for adaptation to a tropicalized eastern Australia. Evol Appl 7:1226-1237

Friederich GE, Ledesma J, Ulloa O, Chavez FP (2008) Airsea carbon dioxide fluxes in the coastal southeastern tropical Pacific. Prog Oceanogr 79:156-166

Fry SC, Miller JG, Dumville JC (2002) A proposed role for copper ions in cell wall loosening. Plant Soil 247:57-67

*Gattuso JP, Magnan A, Billé R, Cheung WWL and others (2015) Contrasting futures for ocean and society from different anthropogenic $\mathrm{CO}_{2}$ emissions scenarios. Science 349:aac4722

Gazeau F, Parker L, Comeau S, Gattuso JP and others (2013) Impacts of ocean acidification on marine shelled mollusks. Mar Biol 160:2207-2245

* Geret F, Bebianno MJ (2004) Does zinc produce reactive oxygen species in Ruditapes decussatus? Ecotoxicol Environ Saf 57:399-409

Geret F, Serafim A, Barreira L, Bebianno MJ (2002) Effect of cadmium on antioxidant enzyme activities and lipid peroxidation in the gills of the clam Ruditapes decussates. Biomarkers 7:242-256

Gibbin EM, Putnam HM, Davy SK, Gates RD (2014) Intracellular $\mathrm{pH}$ and its response to $\mathrm{CO}_{2}$-driven seawater acidification in symbiotic versus non-symbiotic coral cells. J Exp Biol 217:1963-1969

* Gorski J, Nugegoda D (2006) Sublethal toxicity of trace metals to larvae of the blacklip abalone, Haliotis rubra. Environ Toxicol Chem 25:1360-1367

Götze S, Matoo OB, Beniash E, Saborowski R, Sokolova IM (2014) Interactive effects of $\mathrm{CO}_{2}$ and trace metals on the proteasome activity and cellular stress response of marine bivalves Crassostrea virginica and Mercenaria mercenaria. Aquat Toxicol 149:65-82

Graham F, Mackrill T, Davidson M, Daume S (2006) Influence of conditioning diet and spawning frequency on variation in egg diameter for greenlip abalone, Haliotis laevigata. J Shellfish Res 25:195-200

*Go X, Huang M, Pu F, You W, Ke C (2015) Effects of ocean acidification caused by rising $\mathrm{CO}_{2}$ on the early development of three mollusks. Aquat Biol 23:147-157

*Heuer RM, Grosell M (2014) Physiological impacts of elevated carbon dioxide and ocean acidification on fish. Am J Physiol Regul Integr Comp Physiol 307:R1061-R1084

*His E, Seaman MNL, Beiras R (1997) A simplification the bivalve embryogenesis and larval development bioassay method for water quality assessment. Water Res 31: 351-355

Hunt JW, Anderson BS (1990) Abalone larval development: short-term toxicity test protocol. In: Anderson BW, Hunt JW, Turpen SL, Coulon AR, Martin M, McKeown DL, Palmer FH (eds) Procedures manual for conducting toxicity tests developed by the marine bioassay project. California State Water Resources Control Board, Sacramento, CA, p 17-48

* Isani G, Andreani G, Kindt M, Carpenè E (2000) Metallothioneins (MTs) in marine mollusks. Cell Mol Biol 46: 311-330

* Ivanina AV, Beniash E, Etzkorn M, Meyers TB, Ringwood AH, Sokolova IM (2013) Short-term acute hypercapnia affects cellular responses to trace metals in the hard clams Mercenaria mercenaria. Aquat Toxicol 140-141:123-133

Johnson D (1988) Development of Mytilus edulis embryos: a bioassay for polluted waters. Mar Ecol Prog Ser 46: 135-138

Kerndorff H, Schnitzer M (1980) Sorption of metals on humic acid. Geochim Cosmochim Acta 44:1701-1708

Kroeker KJ, Kordas RI, Crim RM, Hendriks IE and others (2013) Impacts of ocean acidification on marine organisms: quantifying sensitivities and interaction with warming. Glob Change Biol 19:1884-1896

Krumschnabel G, Manzl C, Berger C, Hofer B (2005) Oxidative stress, mitochondrial permeability transition, and cell death in $\mathrm{Cu}$-exposed trout hepatocytes. Toxicol Appl Pharmacol 209:62-73

* Lacoue-Labarthe T, Martin S, Oberhänsli F, Teyssié JL, Markich S, Jeffree R, Bustamante P (2009) Effects of increased $\mathrm{pCO}_{2}$ and temperature on trace element ( $\mathrm{Ag}$, $\mathrm{Cd}$ and $\mathrm{Zn}$ ) bioaccumulation in the eggs of the common cuttlefish Sepia officinalis. Biogeosciences 6:2561-2573

* Lewis C, Clemow K, Holt WV (2013) Metal contamination increases the sensitivity of larvae but not gametes to ocean acidification in the polychaete Pomatoceros lamarckii (Quatrefages). Mar Biol 160:2089-2101

* Li Y, Wang WX, Wang M (2017) Alleviation of mercury toxicity to a marine copepod under multigenerational exposure by ocean acidification. Sci Rep 7:324

Kindsey R (2020) Climate change: atmospheric carbon dioxide. www.climate.gov/news-features/understanding-climate/ climate-change-atmospheric-carbon-dioxide

Lopes AF, Morais P, Pimentel M, Rosa R, Munday PL, Gonçalves EJ, Faria AM (2016) Behavioural lateralization and shoaling cohesion of fish larvae altered under ocean acidification. Mar Biol 163:243

* Martelli A, Rousselet E, Dycke C, Bouron A, Moulis JM (2006) Cadmium toxicity in animal cells by interference with essential metals. Biochimie 88:1807-1814

Melzner F, Thomsen J, Koeve W, Oschlies A and others (2013) Future ocean acidification will be amplified by hypoxia in coastal habitats. Mar Biol 160:1875-1888

* Millero FJ, Woosley R, Ditrolio B, Waters J (2009) Effect of ocean acidification on the speciation of metals in seawater. Oceanography 22:72-85 
Morita M, Suwa R, Iguchi A, Nakamura M, Shimada K, Sakai K, Suzuki A (2010) Ocean acidification reduces sperm flagellar motility in broadcast spawning reef invertebrates. Zygote 18:103-107

Moulin L, Catarino AI, Claessens T, Dubois P (2011) Effects of seawater acidification on early development of the intertidal sea urchin Paracentrotus lividus (Lamarck 1816). Mar Pollut Bull 62:48-54

Pan K, Wang WX (2012) Trace metal contamination in estuarine and coastal environments in China. Sci Total Environ 421-422:3-16

Parker LM, Ross PM, O'Connor WA, Borysko L, Raftos DA, Pörtner HO (2012) Adult exposure influences offspring response to ocean acidification in oysters. Glob Change Biol 18:82-92

* Pascal PY, Fleeger JW, Galvez F, Carman KR (2010) The toxicological interaction between ocean acidity and metals in coastal meiobenthic copepods. Mar Pollut Bull 60: 2201-2208

Reichelt-Brushett AJ, Harrison PL (1999) The effect of copper, zinc and cadmium on fertilization success of gametes from scleractinian reef corals. Mar Pollut Bull 38:182-187

Reichelt-Brushett AJ, Michalek-Wagner K (2005) Effects of copper on the fertilization success of the soft coral Lobophytum compactum. Aquat Toxicol 74:280-284

Reum JCP, Alin SR, Harvey CJ, Bednaršek N and others (2016) Interpretation and design of ocean acidification experiments in upwelling systems in the context of carbonate chemistry Co-variation with temperature and oxygen. ICES J Mar Sci 73:582-595

Reuter KE, Lotterhos KE, Crim RN, Thompson CA, Harley CDG (2011) Elevated $\mathrm{pCO}_{2}$ increases sperm limitation and risk of polyspermy in the red sea urchin Strongylocentrotus franciscanus. Glob Change Biol 17:163-171

Ringwood AH, Conners DE, Dinovo A (1998) The effects of copper exposures on cellular responses in oysters. Mar Environ Res 46:591-595

Roesijadi G, Hansen KM, Unger ME (1996) Cadmiuminduced metallothionein expression during embryonic and early larval development of the mollusc Crassostrea virginica. Toxicol Appl Pharmacol 140:356-363

Sabine CL, Feely RA, Gruber N, Key RM and others (2004) The oceanic sink for anthropogenic $\mathrm{CO}_{2}$. Science 305: 367-371

Sawatari H, Fujimori E, Haraguchi H (1995) Multi-element determination of trace elements in seawater by gallium coprecipitation and inductively coupled plasma mass spectrometry. Anal Sci 11:369-374

Schäfer S, Bickmeyer U, Koehler A (2009) Measuring Ca ${ }^{2+}$ signalling at fertilization in the sea urchin Psammechinus miliaris: alterations of this $\mathrm{Ca}^{2+}$-signal by copper and 2,4,6-tribromophenol. Comp Biochem Physiol C Toxicol Pharmacol 150:261-269

Schlegel P, Binet MT, Havenhand JN, Doyle CJ, Williamson JE (2015) Ocean acidification impacts on sperm mitochondrial membrane potential bring sperm swimming behaviour near its tipping point. J Exp Biol 218:1084-1090

Schubauer-Berigan MK, Dierkes JR, Monson PD, Ankley GT (1993) pH-dependent toxicity of $\mathrm{Cd}, \mathrm{Cu}, \mathrm{Ni}, \mathrm{Pb}$ and Zn to Ceriodaphnia dubia, Pimephales promelas, Hyalella azteca and Lumbriculus variegatus. Environ Toxicol Chem 12:1261-1266

Shi W, Zhao X, Han Y, Che Z, Chai X, Liu G (2016) Ocean acidification increases cadmium accumulation in marine bivalves: a potential threat to seafood safety. Sci Rep 6: 20197

Shi W, Han Y, Guo C, Zhao X and others (2017) Ocean acidification hampers sperm-egg collisions, gamete fusion, and generation of $\mathrm{Ca}^{2+}$ oscillations of a broadcast spawning bivalve, Tegillarca granosa. Mar Environ Res 130: 106-112

Stohs SJ, Bagchi D (1995) Oxidative mechanisms in the toxicity of metal ions. Free Radic Biol Med 18:321-336

* Stumpp M, Dupont S, Thorndyke MC, Melznera F (2011) $\mathrm{CO}_{2}$ induced seawater acidification impacts sea urchin larval development II: gene expression patterns in pluteus larvae. Comp Biochem Physiol A Mol Integr Physiol 160:320-330

* Suphamungmee W, Chansela P, Weerachatyanukul W, Poomtong T, Vanichviriyakit R, Sobhon, P (2010) Ultrastructure, composition, and possible roles of the egg coats in Haliotis asinina. J Shellfish Res 29:687-697

* Thomas RC, Meech RW (1982) Hydrogen ion currents and intracellular $\mathrm{pH}$ in depolarized voltage-clamped snail neurones. Nature 299:826-828

* Thomsen J, Stapp LS, Haynert K, Schade H and others (2017) Naturally acidified habitat selects for ocean acidification-tolerant mussels. Sci Adv 3:e1602411

*Todgham AE, Hofmann GE (2009) Transcriptomic response of sea urchin larvae Strongylocentrotus purpuratus to $\mathrm{CO}_{2}$-driven seawater acidification. J Exp Biol 212: 2579-2594

* Ulanowicz RE, Tuttle JH (1992) The trophic consequences of oyster stock rehabilitation in Chesapeake Bay. Estuaries 15:298-306

*Unger ME, Roesijadi G (1996) Cd preexposure and increase in metallothionein mRNA accumulation during subsequent Cd challenge. Aquat Toxicol 34:185-193

Vacquier VD, Swanson WJ, Metz EC, Stout CD (1999) Acrosomal proteins of abalone spermatozoa. Adv Dev Biochem 5:49-81

Valko M, Morris H, Cronin MT (2005) Metals, toxicity and oxidative stress. Curr Med Chem 12:1161-1208

* Viarengo A, Pertica M, Mancinelli G, Burlando B, Canesi L, Orunesu M (1996) In vivo effects of copper on the calcium homeostasis mechanism of mussel gill cell plasma membranes. Comp Biochem Physiol C Pharmacol Toxicol Endocrinol 113:421-425

Victor S, Richmond RH (2005) Effect of copper on fertilization success in the reef coral Acropora surculosa. Mar Pollut Bull 50:1448-1451

*Vitale AM, Monserrat JM, Castilho P, Rodriguez EM (1999) Inhibitory effects of cadmium on carbonic anhydrase activity and ionic regulation of the estuarine crab Chasmagnathus granulata (Decapoda, Grapsidae). Comp Biochem Physiol C Pharmacol Toxicol Endocrinol 122: 121-129

* Wang WX, Yang Y, Guo X, He M, Guo F, Ke C (2011) Copper and zinc contamination in oysters: subcellular distribution and detoxification. Environ Toxicol Chem 30: 1767-1774

* Wang Q, Cao R, Ning X, You L and others (2016) Effects of ocean acidification on immune responses of the Pacific oyster Crassostrea gigas. Fish Shellfish Immunol 49:24-33

*Weng N, Wang WX (2014) Variations of trace metals in two estuarine environments with contrasting pollution histories. Sci Total Environ 485-486:604-614

Zhai W (2018) Exploring seasonal acidification in the Yellow Sea. Sci China Earth Sci 61:647-658 


\section{APPENDIX.}

Table A1. Cu and $\mathrm{Zn}$ concentrations of test solutions used in experiments testing larval deformation and shell length in Crassostrea angulata

\begin{tabular}{|c|c|c|c|c|}
\hline \multicolumn{2}{|c|}{ Replicate } & \multirow{2}{*}{$\begin{array}{c}\mathrm{pCO}_{2} \\
(\mu \mathrm{tm})\end{array}$} & \multirow{2}{*}{$\begin{array}{c}\begin{array}{c}\text { Norminal concen- } \\
\text { tration }\left(\mu \mathrm{g} \mathrm{l}^{-1}\right)\end{array} \\
5\end{array}$} & \multirow{2}{*}{$\begin{array}{c}\begin{array}{c}\text { Tested concen- } \\
\text { tration }\left(\mu \mathrm{g} \mathrm{l}^{-1}\right)\end{array} \\
5.43\end{array}$} \\
\hline $\mathrm{Cu}$ & 1 & & & \\
\hline & 2 & 400 & 5 & 5.49 \\
\hline & 3 & 400 & 5 & 5.23 \\
\hline & 4 & 400 & 5 & 5.80 \\
\hline & 1 & 400 & 10 & 10.64 \\
\hline & 2 & 400 & 10 & 10.37 \\
\hline & 3 & 400 & 10 & 10.27 \\
\hline & 4 & 400 & 10 & 10.36 \\
\hline & 1 & 800 & 5 & 5.16 \\
\hline & 2 & 800 & 5 & 5.82 \\
\hline & 3 & 800 & 5 & 5.61 \\
\hline & 4 & 800 & 5 & 5.83 \\
\hline & 1 & 800 & 10 & 9.11 \\
\hline & 2 & 800 & 10 & 10.90 \\
\hline & 3 & 800 & 10 & 10.08 \\
\hline & 4 & 800 & 10 & 10.78 \\
\hline & 1 & 1500 & 5 & 5.12 \\
\hline & 2 & 1500 & 5 & 5.23 \\
\hline & 3 & 1500 & 5 & 5.16 \\
\hline & 4 & 1500 & 5 & 4.73 \\
\hline & 1 & 1500 & 10 & 9.66 \\
\hline & 2 & 1500 & 10 & 9.23 \\
\hline & 3 & 1500 & 10 & 9.66 \\
\hline & 4 & 1500 & 10 & 10.20 \\
\hline $\mathrm{Zn}$ & 1 & 400 & 25 & 28.98 \\
\hline & 2 & 400 & 25 & 28.54 \\
\hline & 3 & 400 & 25 & 30.01 \\
\hline & 4 & 400 & 25 & 27.09 \\
\hline & 1 & 400 & 50 & 51.64 \\
\hline & 2 & 400 & 50 & 51.45 \\
\hline & 3 & 400 & 50 & 52.07 \\
\hline & 4 & 400 & 50 & 53.86 \\
\hline & 1 & 800 & 25 & 26.41 \\
\hline & 2 & 800 & 25 & 27.59 \\
\hline & 3 & 800 & 25 & 27.69 \\
\hline & 4 & 800 & 25 & 25.50 \\
\hline & 1 & 800 & 50 & 53.99 \\
\hline & 2 & 800 & 50 & 54.15 \\
\hline & 3 & 800 & 50 & 51.33 \\
\hline & 4 & 800 & 50 & 52.21 \\
\hline & 1 & 1500 & 25 & 27.26 \\
\hline & 2 & 1500 & 25 & 30.40 \\
\hline & 3 & 1500 & 25 & 30.13 \\
\hline & 4 & 1500 & 25 & 29.82 \\
\hline & 1 & 1500 & 50 & 55.74 \\
\hline & 2 & 1500 & 50 & 54.88 \\
\hline & 3 & 1500 & 50 & 57.71 \\
\hline & 4 & 1500 & 50 & 52.09 \\
\hline
\end{tabular}

